\title{
Characterization of submicron particles influenced by mixed biogenic and anthropogenic emissions using high-resolution aerosol mass spectrometry: results from CARES
}

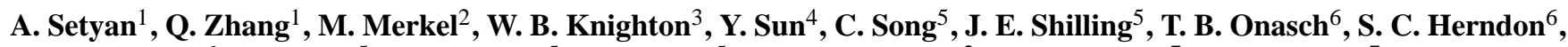 \\ D. R. Worsnop ${ }^{6}$, J. D. Fast ${ }^{5}$, R. A. Zaveri ${ }^{5}$, L. K. Berg ${ }^{5}$, A. Wiedensohler ${ }^{2}$, B. A. Flowers ${ }^{7}$, M. K. Dubey ${ }^{7}$, and \\ R. Subramanian 8 \\ ${ }^{1}$ Department of Environmental Toxicology, University of California, 1 Shields Ave., Davis, CA 95616, USA \\ ${ }^{2}$ Leibniz Institute for Tropospheric Research, 04318 Leipzig, Germany \\ ${ }^{3}$ Montana State University, Bozeman, MT 59717, USA \\ ${ }^{4}$ State Key Laboratory of Atmospheric Boundary Layer and Atmospheric Chemistry, Institute of Atmospheric Physics, \\ Chinese Academy of Sciences, Beijing, China \\ ${ }^{5}$ Pacific Northwest National Laboratory, Richland, WA 99352, USA \\ ${ }^{6}$ Aerodyne Research Inc., Billerica, MA 01821, USA \\ ${ }^{7}$ Los Alamos National Laboratory, Los Alamos, NM 87545, USA \\ ${ }^{8}$ RTI International, RTP, NC 27709, USA
}

Correspondence to: Q. Zhang (dkwzhang@ucdavis.edu)

Received: 4 February 2012 - Published in Atmos. Chem. Phys. Discuss.: 21 February 2012

Revised: 30 July 2012 - Accepted: 27 August 2012 - Published: 11 September 2012

\begin{abstract}
An Aerodyne high resolution time-of-flight aerosol mass spectrometer (HR-ToF-AMS) was deployed during the Carbonaceous Aerosols and Radiative Effects Study (CARES) that took place in northern California in June 2010. We present results obtained at Cool (denoted as the T1 site of the project) in the foothills of the Sierra Nevada Mountains, where intense biogenic emissions are periodically mixed with urban outflow transported by daytime southwesterly winds from the Sacramento metropolitan area. During this study, the average mass loading of submicrometer particles $\left(\mathrm{PM}_{1}\right)$ was $3.0 \mu \mathrm{g} \mathrm{m}^{-3}$, dominated by organics $(80 \%)$ and sulfate $(9.9 \%)$. The organic aerosol (OA) had a nominal formula of $\mathrm{C}_{1} \mathrm{H}_{1.38} \mathrm{~N}_{0.004} \mathrm{O}_{0.44}$, thus an average organic mass-to-carbon (OM/OC) ratio of 1.70 . Two distinct oxygenated OA factors were identified via Positive matrix factorization (PMF) of the high-resolution mass spectra of organics. The more oxidized MO-OOA $(\mathrm{O} / \mathrm{C}=0.54)$ was interpreted as a surrogate for secondary $\mathrm{OA}$ (SOA) influenced by biogenic emissions whereas the less oxidized LO-OOA $(\mathrm{O} / \mathrm{C}=0.42)$ was found to represent SOA formed in photochemically processed urban emis-
\end{abstract}

sions. LO-OOA correlated strongly with ozone and MOOOA correlated well with two 1st generation isoprene oxidation products (methacrolein and methyl vinyl ketone), indicating that both SOAs were relatively fresh. A hydrocarbon like OA (HOA) factor was also identified, representing primary emissions mainly due to local traffic. On average, SOA (= MO-OOA + LO-OOA) accounted for $91 \%$ of the total OA mass and $72 \%$ of the $\mathrm{PM}_{1}$ mass observed at Cool. Twenty three periods of urban plumes from T0 (Sacramento) to T1 (Cool) were identified using the Weather Research and Forecasting model coupled with Chemistry (WRF-Chem). The average $\mathrm{PM}_{1}$ mass loading was considerably higher in urban plumes than in air masses dominated by biogenic SOA. The change in OA mass relative to $\mathrm{CO}$ $(\triangle \mathrm{OA} / \Delta \mathrm{CO})$ varied in the range of $5-196 \mu \mathrm{g} \mathrm{m}^{-3} \mathrm{ppm}^{-1}$, reflecting large variability in SOA production. The highest $\triangle \mathrm{OA} / \triangle \mathrm{CO}$ was reached when air masses were dominated by anthropogenic emissions in the presence of a high concentration of biogenic volatile organic compounds (BVOCs). This ratio, which was $97 \mu \mathrm{g} \mathrm{m}^{-3} \mathrm{ppm}^{-1}$ on average, was much higher than when urban plumes arrived in a low BVOC 
environment $\left(\sim 36 \mu \mathrm{g} \mathrm{m}^{-3} \mathrm{ppm}^{-1}\right)$ or during other periods dominated by biogenic SOA $\left(35 \mu \mathrm{g} \mathrm{m}^{-3} \mathrm{ppm}^{-1}\right)$. These results demonstrate that SOA formation is enhanced when anthropogenic emissions interact with biogenic precursors.

\section{Introduction}

Atmospheric aerosols significantly affect the Earth's climate (IPCC, 2007), human health (Pope et al., 2009), the ecological balance (Mahowald, 2011), and visibility (Watson, 2002). Aerosols consist of a wide range of chemical compounds. Analyses of many datasets from around the world showed that organic species generally represent the dominant fraction and account for 20-90\% of the mass in submicron particles (Zhang et al., 2007a). Organic aerosols (OA) are classified into primary (POA) or secondary (SOA). POA refers to aerosols directly emitted by a source, such as fossil fuel combustion, biomass burning or food cooking, while SOA are generated by reactions of gaseous precursors. In addition, OA can also be classified depending on their sources, e.g., biogenic or anthropogenic.

Models have been developed to improve understanding of aerosol processes and properties, and to evaluate their effects on climate. Even if some uncertainties still remain, the processes controlling the formation and evolution of secondary inorganic aerosol compounds are now well understood (Zaveri et al., 2008). However, since SOA formation is controlled by very complex processes, including photooxidation of volatile organic compounds (VOCs), nucleation or gas-to-particle partitioning of low volatile compounds into preexisting particles, and aqueous-phase and heterogeneous processes (Kanakidou et al., 2005; Hallquist et al., 2009; Ervens et al., 2011), current models have difficulty predicting accurately SOA concentrations and/or properties (e.g., Volkamer et al., 2006; Dzepina et al., 2009; Spracklen et al., 2011). Recent studies suggest that anthropogenic and biogenic emissions may interact and increase SOA formation (Kanakidou et al., 2000; Weber et al., 2007; Goldstein et al., 2009; Hoyle et al., 2011; Worton et al., 2011). Thus, field campaigns have been undertaken in locations subjected to both urban and natural influences to study the enhancement effects of SOA production in mixed biogenic and anthropogenic emissions. These studies are important for identifying missing SOA sources in current models and closing the gaps between simulated and measured SOA concentrations and properties (Zaveri et al., 2012).

The Sacramento Valley, which corresponds to the northern part of the Central Valley of California, is a place of choice to study processes of organic species from biogenic and anthropogenic sources. The valley forms a northwestsoutheast axis and its shape is defined by mountains on the west (various Coast Ranges), north (Siskiyou Mountains) and east (Sierra Nevada Mountains). A mid-size metropoli- tan area (Sacramento and its suburbs) lies on the south edge of the valley, while the rest of the valley is heavily forested and contains large agricultural regions. The Sacramento Valley has faced air pollution problems such as high ozone concentrations promoted by meteorological conditions (strong sunlight and high temperatures in summer) coupled with high VOCs and $\mathrm{NO}_{\mathrm{x}}$ emissions (Murphy et al., 2007). In summer, the region is subjected to constant winds, which bring air masses from the Pacific Ocean to the Sacramento metropolitan area, and push northeast to the Sierra Nevada Mountains, bringing urban outflow from Sacramento to the foothills (Dillon et al., 2002). Recent studies performed at the University of California-Blodgett Forest Research Station (UC-BFRS; Goldstein et al., 2000), which is located on the western slope of the Sierra Nevada $\sim 75 \mathrm{~km}$ downwind from Sacramento and surrounded by a ponderosa pine plantation, pointed out that large amounts of reactive VOCs are emitted by the surrounding forests (e.g., Bouvier-Brown et al., 2009) and that SOA formation in this region is mainly driven by oxidation of monoterpenes and isoprene (Cahill et al., 2006; Worton et al., 2011) mediated primarily by ozone (Holzinger et al., 2005). New particle formation and growth events have been frequently observed as well (Lunden et al., 2006; Creamean et al., 2011), indicating the importance of secondary aerosol formation processes in the region. Several studies also focused on chemical processes occurring in urban plumes brought from Sacramento (Dillon et al., 2002; Spaulding et al., 2003), but anthropogenic influences were found to be small at the UC-BFRS, probably because the site is too far from significant urban emission sources.

The Carbonaceous Aerosols and Radiative Effects Study (CARES), which was sponsored by the US Department of Energy (DOE), took place in northern California in summer 2010. The aim of this field campaign was to better understand the evolution and ageing of carbonaceous aerosols in a region influenced by mixed anthropogenic and biogenic precursors, and to integrate this knowledge into models used for simulating their direct and indirect radiative effects on climate (Zaveri et al., 2012; Fast et al., 2012). Measurements were conducted at two ground-based sites: one within the Sacramento urban area (denoted T0 to represent the urban emission origin of the project) and one at Cool, CA (denoted $\mathrm{T} 1$ to represent a rural receptor site located $\sim 40 \mathrm{~km}$ northeast of Sacramento, i.e., downwind from T0). In coordination with the two ground-based operations, two aircrafts conducted regular flights through and around the Sacramento plumes during CARES. Zaveri et al. (2012) provide a complete overview of the CARES field campaign, including a description of the experimental design and key observations from the two ground-based sites and aircraft platforms.

In this paper, we present results obtained at the $\mathrm{T} 1$ site of CARES, where we deployed an Aerodyne high resolution time-of-flight aerosol mass spectrometer (HR-ToFAMS) in parallel with a scanning mobility particle sizer (SMPS) to characterize the concentration, composition, size 
distribution, and temporal variation of $\mathrm{PM}_{1}$. We performed positive matrix factorization (PMF) of the high resolution mass spectra to identify distinct OA factors and determine their concentrations and mass spectra. These results were combined with collocated measurements of other aerosol properties, trace gases, and meteorological conditions to elucidate the sources of and processes controlling $\mathrm{PM}_{1}$ at $\mathrm{T} 1$. Finally, periods of urban plumes from Sacramento and other air masses dominated by biogenic emissions were determined by the WRF-Chem model (Fast et al., 2012). Aerosols during different periods are compared to study the influence of anthropogenic emissions on the formation of biogenic SOAs.

\section{Methods}

\subsection{Sampling site, instrumentation, meteorological conditions, and time}

The CARES field campaign took place in the Sacramento Valley between 2 and 28 June 2010. A map of the Sacramento Valley with the location of the two ground-based sites is given in Fig. 1a. Measurements reported in this paper were performed at $\mathrm{Cool}\left(\mathrm{T} 1\right.$ site; $38^{\circ} 53^{\prime} \mathrm{N}, 121^{\circ} 00^{\prime} \mathrm{W}$ ) in a maintenance parking lot on the campus of the Northside School. Cool is a small town (2500 inhabitants) located in the foothills of the Sierra Nevada Mountains at an elevation of $\sim 460 \mathrm{~m}$ above sea level. The sampling site is surrounded by forests, and located $\sim 200 \mathrm{~m}$ from the California State Route 49. During summer, Cool is influenced by highly consistent winds bringing urban outflow from Sacramento during the afternoon (Dillon et al., 2002). A complete description of the meteorological conditions during the CARES is given by Fast et al. (2012). In summary, the meteorological conditions were spring like, with high temperatures on average $27^{\circ} \mathrm{C}$ during the day and $14^{\circ} \mathrm{C}$ in the night (Fig. S1a in the Supplement). The prevailing wind was from the southwest during the day and from the northeast in the night (Fig. 1b). The weather was sunny during the entire campaign, except for two cloudy periods on 4 and 24 June 2010. In addition, during the present study, transport of pollutants from Sacramento over the Sierra Nevada foothills occurred almost every afternoon except for three periods (1013, 16-17, 20-21 June) (Fast et al., 2012).

Various instruments installed in two adjacent trailers were deployed to measure the concentration, chemical composition, size distribution, mixing state, radiative and optical properties, and cloud condensation nuclei (CCN) activities of particles, as well as trace gas concentrations and meteorological conditions (Zaveri et al., 2012). A schematic drawing of the instrumental setup for $\mathrm{PM}_{1}$ is given in Fig. 1c. Particles were sampled through a common inlet equipped with a $\mathrm{PM}_{1}$ impactor (Brechtel Manufacturing Inc., Hayward, CA; model 8003) at a total flow rate of $\sim 151 \mathrm{~min}^{-1}$. The sampling line was constituted of a total of 14 feet of tubing, in-
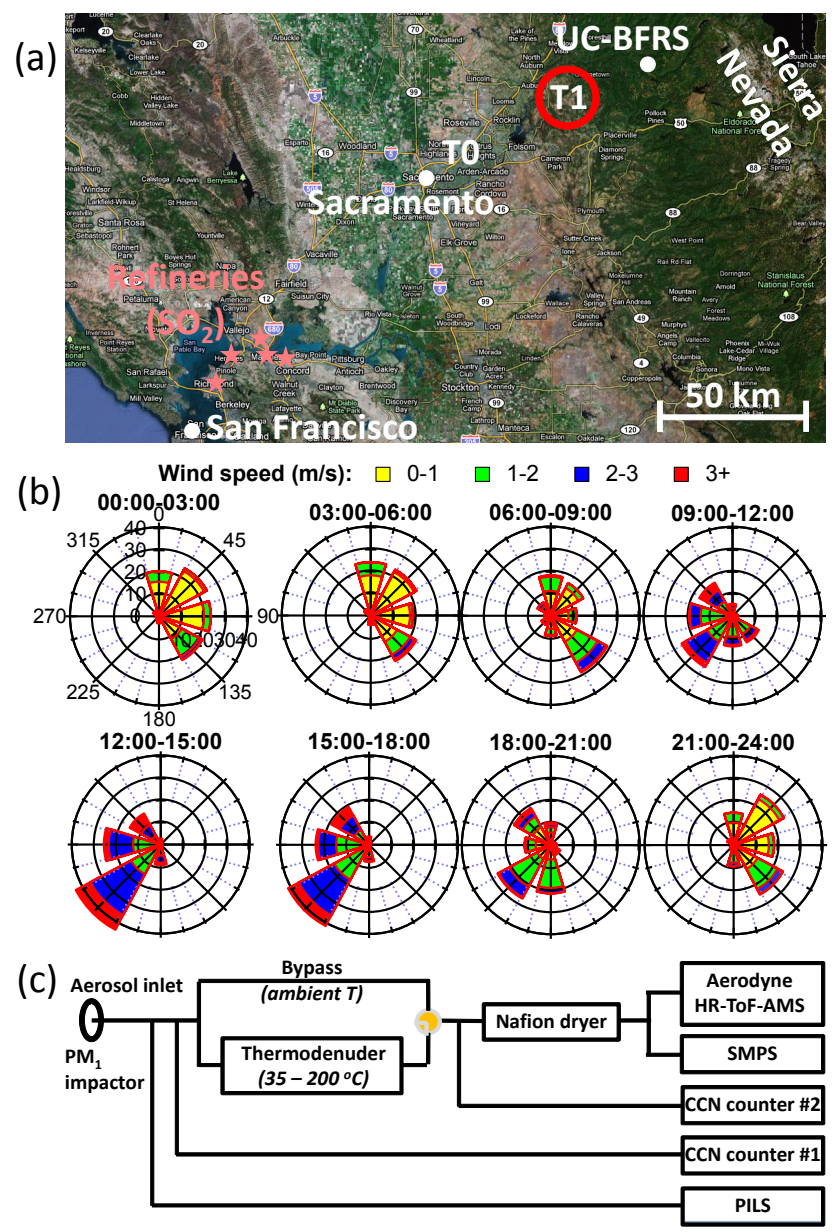

Fig. 1. (a) Map of the Sacramento Valley with the location of the two ground-based sites (T0 and T1), the University of CaliforniaBlodgett Forest Research Station (UC-BFRS, site of the BEARPEX 2007 and 2009 studies) and the refineries identified in the region. (b) Wind rose plots for every 3-h period at the T1 site (height: $3 \mathrm{~m}$ ), colored by wind speed. Radial scales correspond to the frequency, and are kept the same in each wind rose. (c) Schematic drawing of the instrumental setup.

cluding 3 feet of stainless steel tube with an inner diameter of 3/4 inch, 8 feet of copper tube with an inner diameter of $1 / 4$ inch, 2 feet long temperature-controlled thermodenuder (TD), and 1 feet long Nafion dryer. Instruments connected to this system include a particle into liquid sampler (PILS), a $\mathrm{CCN}$ counter, and a thermodenuder. The sampling line downstream of the TD was split again in three parts to connect to an HR-ToF-AMS, an SMPS, and a second CCN counter. The Nafion dryer was included in the system to dry particles analyzed by the HR-ToF-AMS and SMPS. Additional instruments measuring aerosol size and composition, including a single particle soot photometer (SP2) and a particle analysis by laser mass spectrometry (PALMS) system, aerosol optical properties, and trace gases (e.g., VOCs by proton transfer reaction mass spectrometer [PTR-MS], CO by infrared 
absorption, $\mathrm{CO}_{2}$ and $\mathrm{CH}_{4}$ by cavity ring-down spectroscopy [CRDS], and ozone by ultra-violet photometry) were also deployed at $\mathrm{T} 1$, but shared other common inlets.

All dates and times reported in this paper are in Pacific Daylight Time (PDT), which was the local time during this study. PDT corresponds to the Coordinated Universal Time (UTC) minus $7 \mathrm{~h}$ and the Pacific Standard Time (PST) plus $1 \mathrm{~h}$.

\subsection{High resolution time-of-flight aerosol mass spectrometer}

\subsubsection{Operation}

An HR-ToF-AMS was used to measure the size-resolved chemical composition of non-refractory submicron aerosols $\left(\mathrm{NR}-\mathrm{PM}_{1}\right)$ in the size range $35-1000 \mathrm{~nm}$ in $D_{\text {va }}$. The $D_{\text {va }}$ measured by the AMS corresponds to the mobility diameter $\left(D_{\mathrm{m}}\right)$ times the particle density $\left(1.4 \mathrm{~g} \mathrm{~cm}^{-3}\right.$ on average during this study, see Sect. 3.1.1), assuming sphericity (DeCarlo et al., 2004).

In brief, particles are sampled into a high vacuum system $\left(\sim 10^{-5} \mathrm{~Pa}\right)$ through a $100 \mu \mathrm{m}$ critical orifice and an aerodynamic lens installed at the inlet of the instrument. The narrow particle beam formed after the passage through the lens crosses a particle time-of-flight ( $\mathrm{PToF}$ ) region, where the measurement of the velocity allows the determination of the particle diameter $D_{\text {va }}$. Particles are then transmitted into a detection chamber, where non-refractory components (organics, sulfate, nitrate, ammonium, and chloride) are vaporized upon impact on a metallic surface heated up to $\sim 600^{\circ} \mathrm{C}$, and ionized by electron impact $(70 \mathrm{eV})$. The chemical composition of the particles is finally determined by a high resolution time-of-flight mass spectrometer operated alternatively in two modes - "V" and "W". The V-mode is more sensitive than the $\mathrm{W}$-mode, while the mass resolution of the $\mathrm{W}$-mode is higher ( $\sim 5000$ vs. $\sim 2500$ for $\mathrm{V}$-mode).

The data acquisition was performed using the ToFAMS Data Acquisition software v3.0.29, available online at http://cires.colorado.edu/jimenez-group/wiki/index. php/ToF-AMS_DAQ. Between 2 and 17 June 2010, the HRToF-AMS was operated in V-and W-mode alternatively every 2.5 minutes. From 17 June till the end of the field campaign (28 June), a temperature-stepping thermodenuder was operated upstream of the HR-ToF-AMS, SMPS and CCN \#2 (Fig. 1c). During this period, a valve switched automatically every $5 \mathrm{~min}$ to alternate the air flow sampled by the instruments between a bypass (ambient temperature) and the heated section of the thermodenuder. During the bypass period, the HR-ToF-AMS was still operated in V-and W-mode ( $2.5 \mathrm{~min}$ each), while during the thermodenuder period, two runs in V-mode were acquired (also 2.5 min each). PToF data was systematically acquired in $\mathrm{V}$-mode, but not in $\mathrm{W}$-mode, due to low signal/noise ratio.
The ionization efficiency (IE) of the HR-ToF-AMS was calibrated at the beginning, in the middle and at the end of the field campaign, following a standard protocol previously published (Jayne et al., 2000). The IE/air beam ratio varied less than $3 \%$ between the beginning and the end of the campaign, indicating that the instrument remained remarkably stable during the four weeks of the study. For the relative ionization efficiencies (RIEs) of the main chemical species, we used values previously published for organics (1.4), nitrate (1.1) and chloride (1.3) (Alfarra et al., 2004). The RIE of ammonium was determined at 4.0 following the $\mathrm{NH}_{4} \mathrm{NO}_{3}$ analysis during the IE calibrations, and that of sulfate was determined at 1.4 following the analysis of pure $\left(\mathrm{NH}_{4}\right)_{2} \mathrm{SO}_{4}$. The particle sizing was calibrated at the same time as the IE calibration using polystyrene latex spheres of known sizes (Duke Scientific, Palo Alto, CA). A total 13 different sizes in the range of $22-700 \mathrm{~nm}$ were used. Finally, two particulatefree periods were recorded before and after the campaign using a HEPA filter (Pall Corporation, Port Washington, NY; model 12144), for subsequent adjustment of the fragmentation table and determination of the detection limits of individual species (see below).

\subsubsection{Data analysis}

The data analysis was performed using SQUIRREL v1.51 and PIKA v1.10, the standard ToFAMS analysis toolkits written in Igor Pro 6.2.2.2 (WaveMetrics Inc., Lake Oswego, OR) and available online at http://cires.colorado.edu/jimenez-group/ ToFAMSResources/ToFSoftware/index.html. The V-mode and PToF data were processed with SQUIRREL to determine the mass concentrations and size distributions of NR-PM ${ }_{1}$ species. The ammonium concentrations, however, were determined from PIKA analysis of the V-mode data since those from the SQUIRREL analysis are too noisy (see Fig. S2 in the Supplement for a comparison of the ammonium time series). The $\mathrm{W}$-mode data was processed with PIKA to obtain high resolution mass spectra and the elemental composition of organic species.

In order to apportion correctly the ToF-MS signal to the different chemical species, the fragmentation tables of SQUIRREL and PIKA were modified according to the method presented by Allan et al. (2004). A critical modification was the incorporation of a time-dependent correction of the gas-phase $\mathrm{CO}_{2}$ at $\mathrm{m} / \mathrm{z}$ 44. This point was very important, since the gas-phase $\mathrm{CO}_{2}$ showed a strong diurnal pattern (the $\mathrm{CO}_{2}$ concentration was on average $420 \mathrm{ppm}$ during the night and $390 \mathrm{ppm}$ during the day) and that the gas-phase $\mathrm{CO}_{2}$ signal accounted for up to $75 \%$ of the total signal of the $\mathrm{CO}_{2}^{+}$fragment during periods of low organics mass loading. The detection limit of individual species was determined as three times the standard deviation of the corresponding signal in particle-free air (Zhang et al., 2005b). The 2.5-min detection limits (DLs) are 0.075 (organics), 0.011 (sulfate), 0.018 
(nitrate), 0.01 (ammonium), and $0.017 \mu \mathrm{g} \mathrm{m}^{-3}$ (chloride). These values are between 2 and 10 times higher than the DLs (scaled to 2.5-min) reported by DeCarlo et al. (2006), which were 0.014 (organics), 0.0033 (sulfate), 0.002 (nitrate), 0.024 (ammonium), and 0.008 (chloride) $\mu \mathrm{g} \mathrm{m}^{-3}$.

A collection efficiency (CE) was introduced to take into account of incomplete detection of aerosols, due to e.g., particle bounce at the vaporizer (Matthew et al., 2008). In many previous field campaigns, a constant $\mathrm{CE}$ of 0.5 for all the species has been found to be consistent with results obtained with collocated instruments (e.g., DeCarlo et al., 2008; Aiken et al., 2009; Sun et al., 2010; Sun et al., 2011). However, CE may increase depending on the chemical composition (e.g., mass fraction of $\mathrm{NH}_{4} \mathrm{NO}_{3}$ ), acidity, water content and the phase of the particle (Kleinman et al., 2007; Middlebrook et al., 2012). We use a constant CE of 0.5 for all the species in this study, because (1) particles were dominated by organics during the entire campaign (see Sect. 3.1.1), (2) they appeared to be fully neutralized (Fig. 4), and (3) the air flow was dried (relative humidity $-\mathrm{RH}<30 \%$ ) prior to the AMS analysis. This choice has been validated by the inter-comparison between AMS+BC mass and SMPS volume (Figs. 2a and 3).

PMF analysis was performed on the high resolution mass spectra of organic species to determine the mass spectra of distinct organic factors and their time-dependent concentrations. This technique was described by Paatero and Tapper (1994), while its application to AMS datasets was discussed previously (Lanz et al., 2007; Ulbrich et al., 2009; Zhang et al., 2011; Ulbrich et al., 2012). Data and error matrices were first generated in PIKA. We took into account ions up to $\mathrm{m} / \mathrm{z}, 100$, given that bigger ions had low signal/noise ratio and more biases because of insufficient mass resolution. Isotopes were systematically constrained in PIKA, but were removed from the data and error matrices, since their presence would have given excess weight to the parent ions in the PMF analysis. The error matrix was then further adjusted to take into account of the counting error of ions by the detector (Ulbrich et al., 2009). Ions with a signal-to-noise ratio $(\mathrm{S} / \mathrm{N})<0.2$ were removed from the data and error matrices, whereas ions whose average $\mathrm{S} / \mathrm{N}$ between 0.2 and 2 were down-weighed by a factor of 3 . Four organic ions scaled to the $\mathrm{CO}_{2}^{+}$signal $\left(\mathrm{O}^{+}, \mathrm{HO}^{+}, \mathrm{H}_{2} \mathrm{O}^{+}\right.$, and $\left.\mathrm{CO}^{+}\right)$were removed from the data and error matrices prior to the PMF analysis. They were reintroduced in the mass spectra after the PMF analysis. PMF analysis was performed using the PMF Evaluation Tool Software v2.03A described in Ulbrich et al. (2009), available online at http://cires.colorado.edu/jimenez-group/ wiki/index.php/PMF-AMS_Analysis_Guide. The PMF solution has been tested from 1 to 10 factors and for FPEAK values between -1 and +1 (step: 0.1 ). The robustness of the solution has been examined by running the PMF algorithm from different random starting points (SEED values from 0 to 10 , delta $=1$ ). Detailed procedures listed in Table 1 of Zhang et al. (2011) were followed to evaluate various PMF solutions. A summary of the evaluation of the PMF results is given in the Supplement Figs. S5 and S6. The 3-factor solution with FPEAK $=0$ was chosen as the final solution and the results were validated based on interpretation of the characteristic mass spectral signatures, the temporal and diurnal variation patterns of the OA factors in reference to meteorological conditions, and the correlations with tracer compounds (see Sect. 3.2 for details).

\subsection{Collocated measurements}

An SMPS was used to measure the particle number size distribution in the range from 8 to $858 \mathrm{~nm}$ in $D_{\mathrm{m}}$. The SMPS used during this study followed a recommended standard design of the European supersites (Wiedensohler et al., 2012) for atmospheric measurements and was manufactured by the WMO-GAW World Calibration Center for Aerosol Physics (WCCAP) hosted at the Leibnitz Institute for Tropospheric Research (IFT) at Leipzig, Germany. The instrument consists of a neutralizer $\left(\mathrm{Po}^{210}\right)$, a Hauke-type differential mobility analyzer (DMA; design described by Winklmayr et al., 1991) and a condensation particle counter (CPC; TSI Inc., Shoreview, MN; model 3772). The SMPS alternated between two modes - the "upscan" mode (from 8 to $858 \mathrm{~nm}$ ) and the "downscan" mode (from 858 to $8 \mathrm{~nm}$ ) - every $2.5 \mathrm{~min}$. The data was recorded every $5 \mathrm{~min}$, corresponding to the average of the "upscan" and "downscan" modes alternatively. The aerosol sampling flow was set at $11 \mathrm{~min}^{-1}$, and was obtained by using a vacuum pump (GAST Manufacturing Inc., Benton Harbor, MI; model DOA-P704-AA) connected to the outlet of the CPC. The sheath flow was set at $51 \mathrm{~min}^{-1}$. The data acquisition software applied two corrections to the particle size distribution during the data inversion, in order to take into account the DMA transfer function (Birmili et al., 1997) and the bipolar charge distribution (Wiedensohler, 1988). The corrections for the CPC efficiency and the internal diffusion losses were applied after the data inversion. The diffusion losses were calculated following the methods of the "equivalent length" (Wiedensohler et al., 2012).

A PTR-MS (de Gouw and Warneke, 2007) was used for online monitoring of VOCs. Briefly, $\mathrm{H}_{3} \mathrm{O}^{+}$ions are produced in a hollow-cathode discharge in water vapor, and are injected into the drift tube reaction region where they interact with the ambient sample. These reagent ions are pulled through the ambient sample at reduced pressure $(\sim 2$ mbar $)$ under the influence of an applied electric field where they will transfer a proton to any component having a proton affinity greater than that of water. A fraction of the reagent ions and product ions formed are sampled through a small aperture at the end of the drift tube and mass analyzed using a quadrupole mass spectrometer operated in the ion counting mode. For the present study, the ratio between the electric field strength and the buffer gas density (E/N ratio) was 133$136 \mathrm{Td}$ between 2 and 4 June 2010, and 139 Td from 4 June until the end of the campaign. 
The black carbon (BC) concentration was measured with an SP2 (Droplet Measurement Technologies, Boulder, CO; Subramanian et al., 2010). Briefly, particles containing BC absorb energy from an Nd:YAG laser and are heated to the point of incandescence. The incandescence is measured and correlated to the particle's $\mathrm{BC}$ mass using $\mathrm{BC}$ proxies; the results presented here are based on an Acheson Aquadag $®$-based calibration. In addition, the concentrations of CO (Teledyne Technologies Inc., Thousand Oaks, CA; model M300EU), $\mathrm{CO}_{2}$ and $\mathrm{CH}_{4}$ (Picarro Inc., Santa Clara, CA; model 1301G-M), and $\mathrm{O}_{3}$ (Thermo Scientific, Waltham, MA; model 49i) were measured.

\subsection{WRF-Chem and air mass classification}

The WRF-Chem model was used to determine periods of urban plumes from T0 to T1. Details on the operation of the model are given by (Fast et al. (2012). Briefly, the model was run to forecast the spatial and temporal variations of $\mathrm{CO}$ emitted by 20 anthropogenic sources. The spatial distribution of these sources includes regions from the San Francisco Bay Area up to the Sierra Nevada foothills, and from the Sacramento Valley to Southern California. Urban plumes were determined as periods during which $\mathrm{CO}$ emitted in the Sacramento region contributed to more than $30 \%$ of the total anthropogenic $\mathrm{CO}$ at T1. In total, 23 periods of urban plumes were identified during this study, brought by southwesterly wind favorable to the transport of pollutants from Sacramento to Cool. Eight of these periods were characterized by an air mass transported directly from Sacramento to Cool following a straight path, while during twelve other periods the air mass was transported either to the north or to the south of $\mathrm{T} 1$ before being redirected to $\mathrm{T} 1$. The remaining three periods consisted of recirculation of aged plumes over the foothills. A second modeling system, the North American Mesoscale (NAM), identified three periods (10-13, 16-17, 20-21 June) during which the meteorology was characterized by the passage of mid-tropospheric troughs over California, resulting in a shift of the wind direction from the southwest to the northwest. Therefore, during these eight days, urban plumes were transported to the southeast of Sacramento while the T1 site was influenced by clean air masses coming from the northwest, reducing considerably the concentration of pollutants at T1. Finally, another air mass was brought to the T1 site during the night, when the decrease of the temperature reversed the wind direction and favored downslope flows from the western Sierra Nevada back to the Sacramento Valley. These different periods determined by model predictions and given by Fast et al. (2012) were slightly refined in the present study using wind data recorded at T1 and the results of the PMF analysis, which identified among others an oxygenated organic aerosol (OOA) component resulting from urban transport (see Sect. 3.2). The periods are marked in Fig. 2.

\section{Results and discussions}

\subsection{Overview of submicron aerosol characteristics}

\subsubsection{Concentrations and chemical composition of submicron aerosols}

The particle mass concentration was low at T1, varied between 0.4 and $13.8 \mu \mathrm{g} \mathrm{m}^{-3}$ and the average over the entire study was $3.0 \mu \mathrm{g} \mathrm{m}^{-3}$ (Table 1). The chemical composition was dominated by organics, which on average accounted for $80 \%$ of the total particle mass. The other components included sulfate $(9.9 \%)$, ammonium $(4.5 \%)$, nitrate $(3.6 \%)$, and $\mathrm{BC}(1.6 \%)$. The chloride concentrations measured by the HR-ToF-AMS were mostly below detection limit during the present study. Similar $\mathrm{PM}_{1}$ composition and loading were determined during the BEARPEX 2007 field campaign at the Blodgett Forest, which is located $35 \mathrm{~km}$ to the northeast (i.e., downwind) of the site of this study (Farmer et al., 2011; Worton et al., 2011). While forest fires may occur in the region during summer (Worton et al., 2011) we found no indication of wildfires based on the time series of Org 60 (mainly the $\mathrm{C}_{2} \mathrm{H}_{4} \mathrm{O}_{2}^{+}$ion) and $\mathrm{Org} 73\left(\mathrm{C}_{3} \mathrm{H}_{5} \mathrm{O}_{2}^{+}\right)$, two key tracers of biomass burning in AMS mass spectra (Alfarra et al., 2007; Aiken et al., 2010). In addition, the potassium signal recorded by the HR-ToF-AMS and the gas phase acetonitrile measured by the PTR/MS (Fig. S1f) remained low during the entire study, further confirming the lack of biomass burning influence at $\mathrm{T} 1$.

The AMS and SMPS agreed very well throughout this study (Fig. 3). The slope of the linear regression (1.42) corresponds to the average particle density throughout the study, and is consistent with results obtained with a single particle laser ablation time-of-flight mass spectrometer deployed at the T0 site (Vaden et al., 2011). We estimated the density of organics at $1.33 \mathrm{~g} \mathrm{~cm}^{-3}$ by subtracting the contribution of the other chemical species, using the known densities for ammonium sulfate $\left(1.78 \mathrm{~g} \mathrm{~cm}^{-3}\right)$, ammonium nitrate $\left(1.72 \mathrm{~g} \mathrm{~cm}^{-3}\right)$ and ammonium chloride $\left(1.53 \mathrm{~g} \mathrm{~cm}^{-3}\right)$, and a density of $1.8 \mathrm{~g} \mathrm{~cm}^{-3}$ for BC based on values recommended by Bond and Bergstrom (2006). We also predicted the density of organics $\left(\rho_{\text {org }}\right)$ using the average $\mathrm{O} / \mathrm{C}$ and $\mathrm{H} / \mathrm{C}$ ratios based on the formula reported in Kuwata et al. (2012):

$\rho_{\text {org }}=[12+1 \cdot(\mathrm{H} / \mathrm{C})+16 \cdot(\mathrm{O} / \mathrm{C})] /[7+5 \cdot(\mathrm{H} / \mathrm{C})+4.15 \cdot(\mathrm{O} / \mathrm{C})]$

in which $\rho_{\text {org }}$ is in $\mathrm{g} \mathrm{cm}^{-3}, \mathrm{H} / \mathrm{C}$ and $\mathrm{O} / \mathrm{C}$ are the average values (1.38 and 0.44 , respectively) of this study (see Sect. 3.1.4). The $\rho_{\text {org }}$ predicted with this method is $1.30 \mathrm{~g} \mathrm{~cm}^{-3}$, very close to the value of 1.33 obtained based on comparison of particulate mass to volume.

Submicrometer particles appeared to be bulk neutralized at $\mathrm{T} 1$, as shown in the scatter plot of the measured $\mathrm{NH}_{4}^{+}$concentration vs. the predicted $\mathrm{NH}_{4}^{+}\left(\mathrm{NH}_{4}^{+}\right.$predicted $)$concentration assuming anions being fully neutralized by $\mathrm{NH}_{4}^{+}$(Fig. 4): 


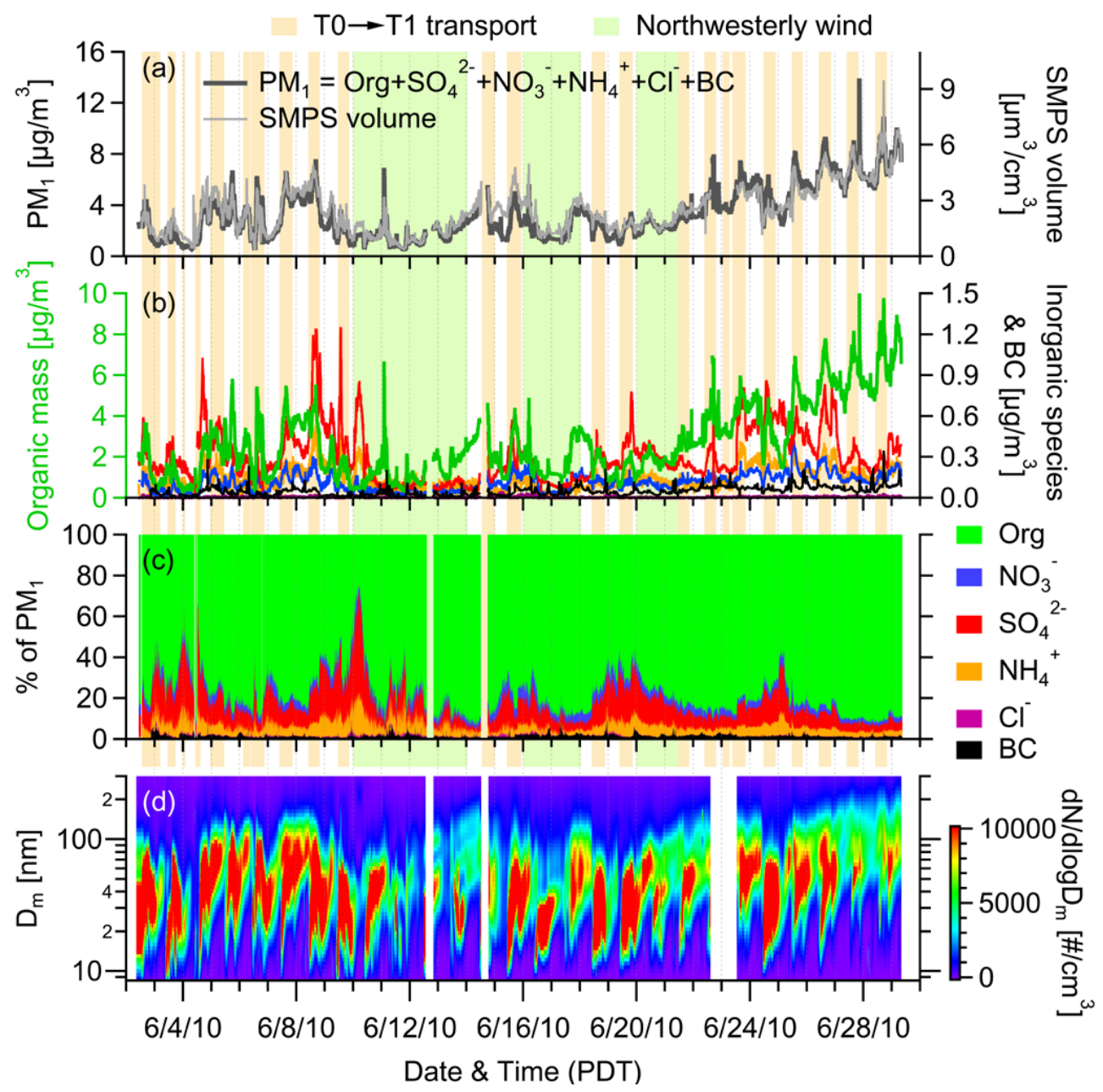

Fig. 2. Time series of (a) AMS total mass + BC and SMPS volume concentrations, (b) concentrations of organics (left y-axis), sulfate, nitrate, ammonium, chloride, and BC (right y-axis), (c) percentage contribution of the species to the total $\mathrm{PM}_{1}$ mass, and (d) particle number size distribution by the SMPS. BC data is not available before 3 June 2010, so $\mathrm{PM}_{1}$ concentrations before this date correspond to the sum of NR-PM 1 (AMS species). Shaded regions indicate 23 periods of urban plumes transported from T0 to T1 (orange) and 3 periods subjected to influences from northwesterly wind (green). The remaining periods correspond mainly to downslope flows from the Sierra Nevada to the foothills.

$\mathrm{NH}_{4}^{+}$predicted $=\left(2 \cdot 18 / 96 \cdot m_{\mathrm{SO}_{4}}\right)+\left(18 / 62 \cdot \mathrm{m}_{\mathrm{NO}_{3}}\right)+\left(18 / 35.5 \cdot m_{\mathrm{Cl}}\right)$

where $\mathrm{m}_{\mathrm{SO}_{4}}, \mathrm{~m}_{\mathrm{NO}_{3}}$, and $\mathrm{m}_{\mathrm{Cl}}$ denote the mass concentrations (in $\mu \mathrm{g} \mathrm{m}^{-3}$ ) of the species and the denominators correspond to their molecular weights. This equation and its application to inferring particle acidity were discussed in detail by Zhang et al. (2007b). The slope is very close to 1 (Fig. 4), suggesting that sulfate was present in the form of ammonium sulfate $\left(\mathrm{NH}_{4}\right)_{2} \mathrm{SO}_{4}$ at $\mathrm{T} 1$. Neutralized particles were observed at the Blodgett Forest as well (Farmer et al., 2011). These results are consistent with the presence of large agricultural regions and thus abundant ammonia emissions in the Sacramento Valley (Clausnitzer and Singer, 1996).

Nitrate accounted for a minor fraction of the particle mass $\left(3.6 \%\right.$; average $\left.=0.11 \mu \mathrm{g} \mathrm{m}^{-3}\right)$ at $\mathrm{T} 1.94 \%$ of the nitrate sig- nal was contributed by two ions, $\mathrm{NO}^{+}(\mathrm{m} / \mathrm{z}, 30)$ and $\mathrm{NO}_{2}^{+}$ $(\mathrm{m} / \mathrm{z}$ 46). In this study, we noticed a much higher slope of $\mathrm{NO}^{+}$vs. $\mathrm{NO}_{2}^{+}$in ambient particles than in pure $\mathrm{NH}_{4} \mathrm{NO}_{3}$ used for the IE calibrations (6.8 vs. 1.7), indicating that an important part of the nitrate signal was not due to ammonium nitrate but possibly corresponded to organonitrates or metal nitrates (Farmer et al., 2010). The $\mathrm{NO}^{+} / \mathrm{NO}_{2}^{+}$ratio can vary dramatically, depending on the nitrate compound. For example, Farmer et al. (2010) report a $\mathrm{NO}^{+} / \mathrm{NO}_{2}^{+}$ratio of 1.5 for $\mathrm{NH}_{4} \mathrm{NO}_{3}$ and an average of 3.5 for various organonitrate standards (min: 1.8 , max: 4.5), while Rollins et al. (2010) measured a NO${ }^{+} / \mathrm{NO}_{2}^{+}$ratio in the range $0.99-5.3$ for laboratory-generated organonitrates and mentioned that this ratio can increase up to 29 for sodium nitrate. Moreover, Shilling et al. (in preparation) found $\mathrm{NO}^{+} / \mathrm{NO}_{2}^{+}$ratios up to 8.8 for organic nitrates generated from trimethylbenzene. 
Table 1. Summary of the average concentrations and $\%$ of total $\mathrm{PM}_{1}$ or VOCs during the entire study and in the three air masses as marked on Fig. 2.

\begin{tabular}{|c|c|c|c|c|c|c|c|c|}
\hline & \multicolumn{2}{|c|}{ Entire study } & \multicolumn{2}{|c|}{$\mathrm{T} 0 \rightarrow \mathrm{T} 1$ transport } & \multicolumn{2}{|c|}{ Northwesterly wind } & \multicolumn{2}{|c|}{ Other periods } \\
\hline & {$\left[\mu \mathrm{g} \mathrm{m}^{-3}\right]$} & {$\left[\%\right.$ of $\left.\mathrm{PM}_{1}\right]$} & {$\left[\mu \mathrm{g} \mathrm{m}^{-3}\right]$} & {$\left[\%\right.$ of $\left.\mathrm{PM}_{1}\right]$} & {$\left[\mu \mathrm{g} \mathrm{m}^{-3}\right]$} & {$\left[\%\right.$ of $\left.\mathrm{PM}_{1}\right]$} & {$\left[\mu \mathrm{g} \mathrm{m}^{-3}\right]$} & [\% of $\left.\mathrm{PM}_{1}\right]$ \\
\hline Organics & 2.4 & 80.4 & 3.1 & 80 & 1.4 & 79 & 2.6 & 81 \\
\hline MO-OOA & 0.97 & $40^{\mathrm{a}}$ & 1.1 & $36^{\mathrm{a}}$ & 0.63 & $44^{\mathrm{a}}$ & 1.1 & $42^{\mathrm{a}}$ \\
\hline LO-OOA & 1.2 & $51^{\mathrm{a}}$ & 1.8 & $57^{\mathrm{a}}$ & 0.61 & $43^{\mathrm{a}}$ & 1.3 & $50^{\mathrm{a}}$ \\
\hline HOA & 0.22 & $9.0^{\mathrm{a}}$ & 0.22 & $7.2^{\mathrm{a}}$ & 0.19 & $13^{\mathrm{a}}$ & 0.23 & $8.6^{\mathrm{a}}$ \\
\hline Sulfate & 0.30 & 9.9 & 0.39 & 10 & 0.18 & 10 & 0.31 & 9.6 \\
\hline Nitrate & 0.11 & 3.6 & 0.13 & 3.5 & 0.070 & 4.0 & 0.12 & 3.5 \\
\hline Ammonium & 0.13 & 4.5 & 0.17 & 4.4 & 0.091 & 5.2 & 0.14 & 4.3 \\
\hline Chloride & 0.002 & 0.1 & $<\mathrm{DL}^{\mathrm{b}}$ & 0.1 & $<\mathrm{DL}^{\mathrm{b}}$ & 0.0 & $<\mathrm{DL}^{\mathrm{b}}$ & 0.1 \\
\hline Black Carbon & 0.07 & 1.6 & 0.054 & 1.4 & 0.032 & 1.8 & 0.053 & 1.6 \\
\hline \multirow[t]{2}{*}{ Total $\mathrm{PM}_{1}^{c}$} & 3.0 & & 3.9 & & 1.8 & & 3.3 & \\
\hline & {$[\mathrm{ppb}]$} & [\% of $\mathrm{VOC}]$ & {$[\mathrm{ppb}]$} & {$[\%$ of $\mathrm{VOC}]$} & [ppb] & [\% of $\mathrm{VOC}]$ & [ppb] & {$[\%$ of $\mathrm{VOC}]$} \\
\hline Photo-oxidation products ${ }^{\mathrm{d}}$ & 7.6 & 82 & 8.3 & 81 & 5.6 & 79 & 7.9 & 83 \\
\hline Biogenic VOCs $\mathrm{e}^{\mathrm{t}}$ & 1.5 & 16 & 1.7 & 17 & 1.3 & 18 & 1.4 & 14 \\
\hline Aromatic $\mathrm{VOCs}^{\mathrm{f}}$ & 0.23 & 2.4 & 0.19 & 1.8 & 0.19 & 2.7 & 0.27 & 2.8 \\
\hline Total VOCs & 9.3 & & 10.2 & & 7.1 & & 9.6 & \\
\hline
\end{tabular}

a $\%$ of total organics

b Detection limit

c Total $\mathrm{PM}_{1}=\mathrm{Org}+\mathrm{SO}_{4}^{2-}+\mathrm{NO}_{3}^{-}+\mathrm{NH}_{4}^{+}+\mathrm{Cl}^{-}+\mathrm{BC}$

$\mathrm{d}$ Photo-oxidation products $=$ acetaldehyde + acetic acid + methacrolein + methyl vinyl ketone + methyl ethyl ketone + formaldehyde + acetone

e Biogenic VOCs = isoprene + monoterpenes + 2-methyl-3-buten-2-ol + methyl chavicol

${ }^{\mathrm{f}}$ Aromatic VOCs $=$ benzene $+\mathrm{C} 2$-benzenes $+\mathrm{C} 3$-benzenes + C4-benzenes + toluene

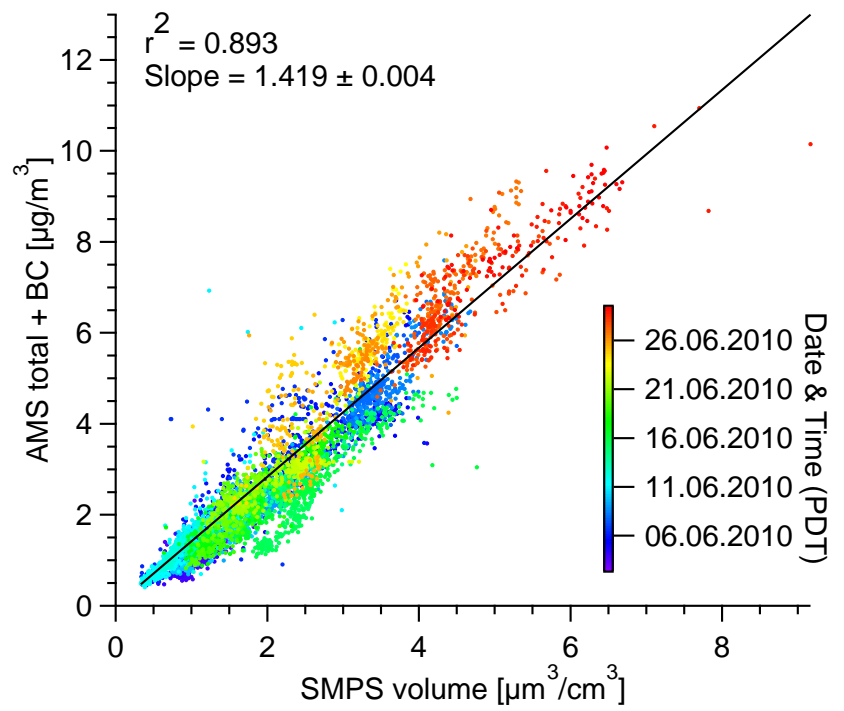

Fig. 3. Scatterplot of AMS total + BC mass vs. SMPS volume in the size range $25-714 \mathrm{~nm}\left(D_{\mathrm{m}}\right)$, colored by time. The data fitting was performed using the orthogonal distance regression (ODR).

In this study, the presence of organonitrates was supported by the fact that 16 ions from the $\mathrm{C}_{\mathrm{x}} \mathrm{H}_{\mathrm{y}} \mathrm{O}_{z} \mathrm{~N}_{p}^{+}$family were observed in high resolution mass spectra, since organonitrates are reported as a source for these fragments (Farmer et al., 2010; Rollins et al., 2010). Moreover, organics and nitrate were correlated during this study $\left(r^{2}=0.54\right.$; Fig. $\left.5 b\right)$,

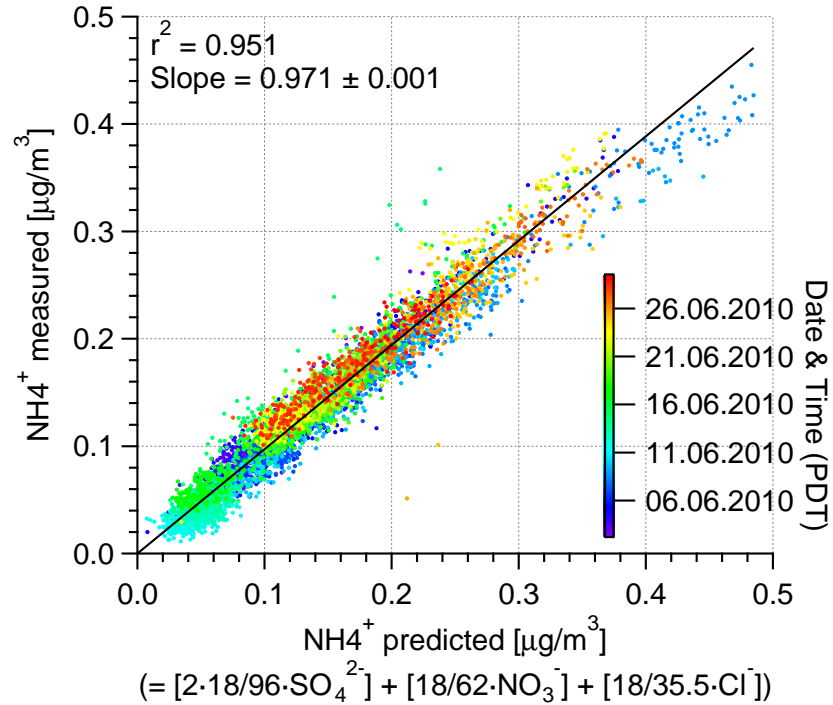

Fig. 4. Scatterplot of $\mathrm{NH}_{4}^{+}$measured vs. $\mathrm{NH}_{4}^{+}$predicted, colored by time. The data fitting was performed using the orthogonal distance regression (ODR).

which could arise if a significant fraction of the nitrate signal corresponded to organonitrates. However, metal nitrates (such as sodium nitrate or potassium nitrate) could have been present as well, given that the $\mathrm{NO}^{+} / \mathrm{NO}_{2}^{+}$ratios observed for ambient aerosols were higher than most of 

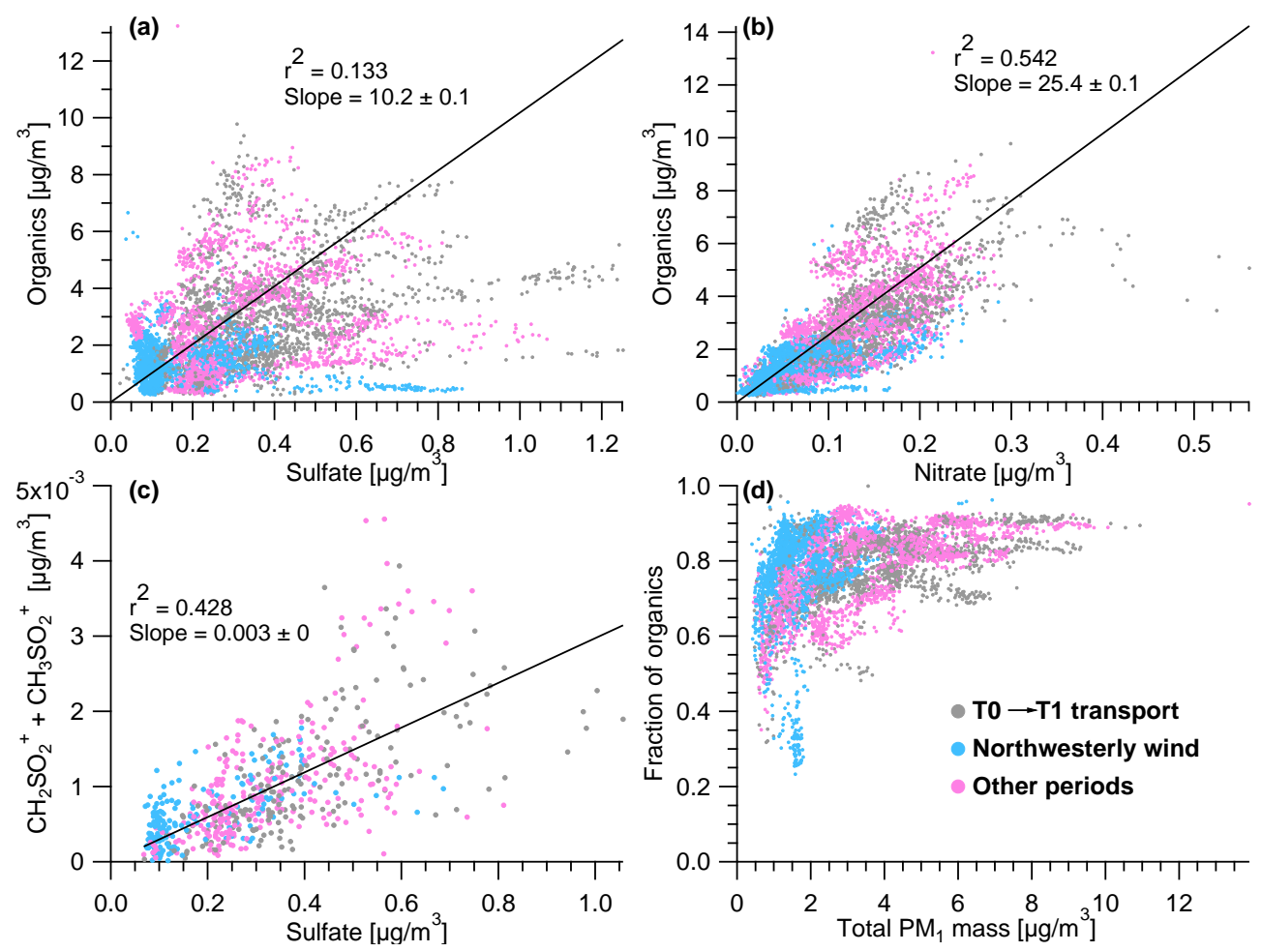

Fig. 5. Scatterplots of (a) organics vs. sulfate, (b) organics vs. nitrate, (c) sum of the main MSA ions vs. sulfate (1-h averaged data), and (d) fraction of organics vs. $\mathrm{PM}_{1}$ mass. All the scatterplots are colored by air mass types. The data fitting was performed using the orthogonal distance regression (ODR).

the organonitrates previously measured (Farmer et al., 2010; Rollins et al., 2010; Shilling et al., 2012).

Organosulfates likely existed as well, given that we detected 11 ions from the $\mathrm{C}_{\mathrm{x}} \mathrm{H}_{\mathrm{y}} \mathrm{S}_{\mathrm{n}} \mathrm{O}_{\mathrm{z}}^{+}(\mathrm{x} \geq 1, \mathrm{y} \geq 1, n \geq 1, \mathrm{z} \geq 0)$ family. Three of them $\left(\mathrm{CH}_{2} \mathrm{SO}_{2}^{+}, \mathrm{CH}_{3} \mathrm{SO}_{2}^{+}\right.$and $\left.\mathrm{CH}_{4} \mathrm{SO}_{3}^{+}\right)$ were unambiguously quantified as they are well separated from adjacent ions in high resolution mass spectra (Ge et al., 2012). These three ions correlated well with each other $\left(r^{2}>0.5\right.$; Fig. S3) and their signal intensity ratios in $\mathrm{T} 1$ aerosols $\left(\mathrm{CH}_{2} \mathrm{SO}_{2}^{+} / \mathrm{CH}_{3} \mathrm{SO}_{2}^{+}=0.32 ; \mathrm{CH}_{4} \mathrm{SO}_{3}^{+} / \mathrm{CH}_{3} \mathrm{SO}_{2}^{+}=\right.$ 0.32 ) were close to those observed in the HR-ToF-AMS mass spectrum of pure methanesulfonic acid (MSA; Ge et al., 2012), indicating the presence of mesylate $\left(\mathrm{CH}_{3} \mathrm{SO}_{3}^{-}\right.$- a salt of MSA) in $\mathrm{PM}_{1}$. However, the total concentration of ions from the $\mathrm{C}_{\mathrm{x}} \mathrm{H}_{\mathrm{y}} \mathrm{S}_{n} \mathrm{O}_{z}^{+}$family was only $2 \mathrm{ng} \mathrm{m}^{-3}$, suggesting very limited contributions of organosulfates to the SOA and sulfate concentrations at $\mathrm{T} 1$. The close molar equivalent balance between the anions ( $=$ sulfate + nitrate + chloride) and ammonium further supports that the observed sulfate signal corresponded mainly to $\left(\mathrm{NH}_{4}\right)_{2} \mathrm{SO}_{4}$.

\subsubsection{Size distribution of submicron aerosols}

The average size distribution of total $\mathrm{PM}_{1}$ mass showed a broad mode extending from 60 to $600 \mathrm{~nm}$ in $D_{\text {va }}$ (Fig. 6a). While $\mathrm{PM}_{1}$ were dominated by organics in the entire size range, larger particles $(>300 \mathrm{~nm})$ had a relatively larger contribution $(\sim 25 \%)$ of ammonium sulfate compared to smaller particles $(<20 \%)$ since these two species had very different size distributions (Fig. 6a). Sulfate showed a bimodal distribution with a prominent droplet accumulation mode at $\sim 400 \mathrm{~nm}$ in $D_{\text {va }}$ and a smaller condensation mode at $\sim 150 \mathrm{~nm}$ (Fig. 6b). In contrast, both organics and nitrate showed a broad distribution that peaks at $150-200 \mathrm{~nm}\left(D_{\mathrm{va}}\right)$. The observation of nitrate in the same size mode as organics was probably because of the contribution of organonitrates to nitrate signals (see discusses in Sect. 3.1.1).

The different size distributions of organics and sulfate and the poor correlation between their concentrations $\left(r^{2}=0.13\right.$; Fig. 5a) suggest major differences in their sources and processes. The prominent droplet mode of sulfate indicates an important influence of aqueous phase reactions on sulfate production. Indeed, the droplet mode particles are too large to be reached by gas-to-particle partitioning of low volatility compounds under typical atmospheric conditions (John et al., 1990; Meng and Seinfeld, 1994), whereas the growth of particles from the condensation mode $\left(<200 \mathrm{~nm}\right.$ in $\left.D_{\mathrm{va}}\right)$ to the droplet mode $\left(400-1000 \mathrm{~nm}\right.$ in $D_{\text {va }}$ ) by coagulation would be too slow with the low aerosol concentrations of the present field campaign. Previous studies have shown that chemical reactions in aqueous phases (i.e., fog and cloud droplets and aerosol phase water) usually add much more 

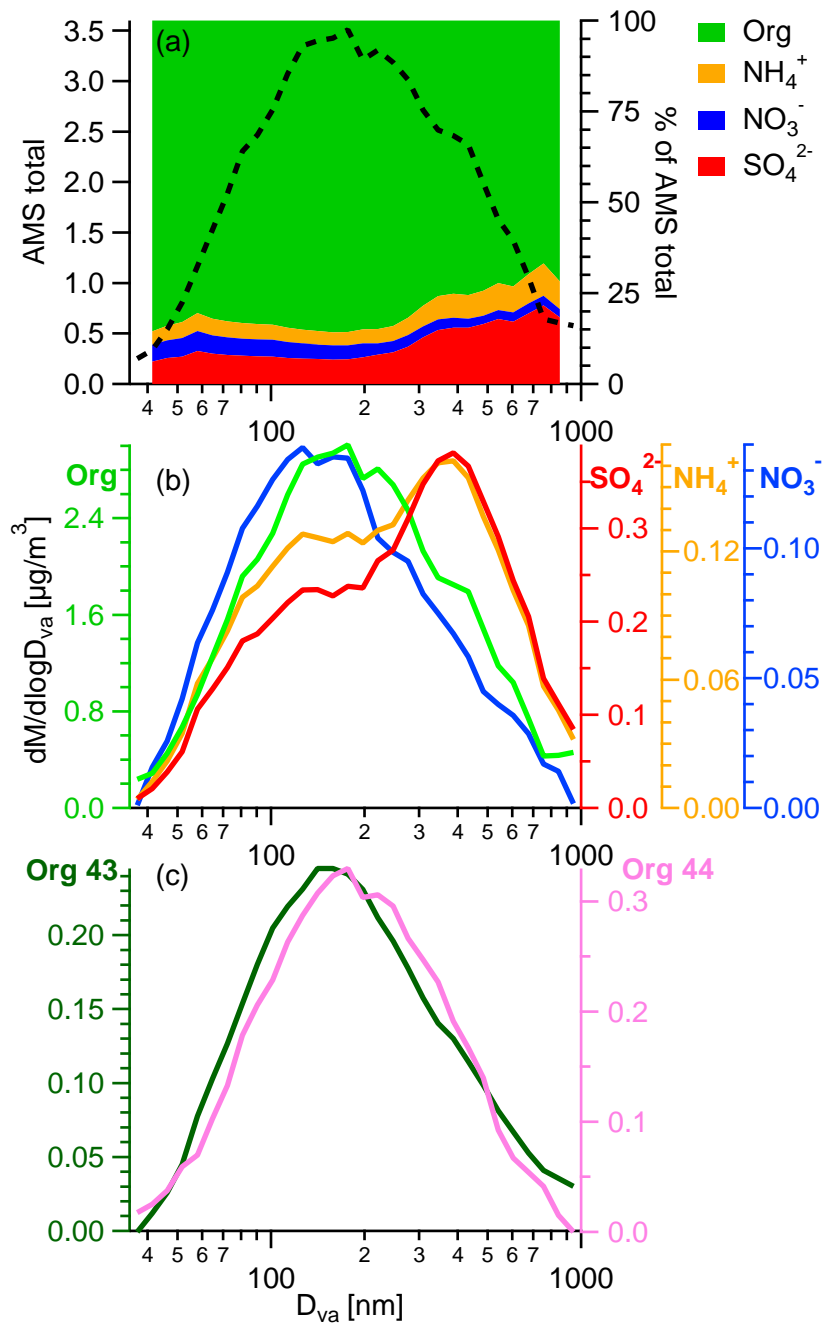

Fig. 6. (a) Average size distributions of the AMS total mass and percentage contribution of aerosol species to total mass, (b) average size distributions of aerosol species, and (c) average size distributions of organic aerosol signals at $\mathrm{m} / \mathrm{z}, 43$ and $\mathrm{m} / \mathrm{z} 44$.

mass in the droplet mode than in smaller particles and that aqueous-phase sulfate formation is an important process in the atmosphere (Ervens et al., 2011, and references therein). In addition, as shown in Fig. 5c, sulfate correlated well with $\mathrm{CH}_{2} \mathrm{SO}_{2}^{+}$and $\mathrm{CH}_{3} \mathrm{SO}_{2}^{+}$, two HR-ToF-AMS ions likely representing MSA or its salts (Ge et al., 2012). MSA is mainly produced by the oxidation of dimethyl sulfide emitted from oceanic sources and its formation is enhanced by aqueous phase processing (Barnes et al., 2006). For these reasons, we deduce that a large fraction of the droplet mode sulfate particles observed during this study likely originated from the San Francisco Bay Area, where the five oil refineries along San Pablo Bay and the Carquinez Straits (Fig. 1a) are the largest $\mathrm{SO}_{2}$ sources in northern California and where regular morning fogs and low clouds may have promoted aqueous phase reactions. This hypothesis is supported by the me- teorological data recorded at Oakland North by the California Air Resources Board (http://www.arb.ca.gov/aqmis2/ metselect.php). Oakland is located on the east of the San Francisco Bay, very close to the oil refineries (Fig. S4a in the Supplement). The RH at Oakland was frequently close to $100 \%$ during the night and in the morning in June 2010 (Fig. S4b and S4c in the Supplement), confirming the frequent occurrence of fogs and low clouds, thus aqueous-phase processing of aerosol particles, in the region.

In contrast, the organic size distribution was dominated by a condensation mode (Fig. 6b). In addition, the average size distributions of $m / z$ 's 43 and 44 , which are the two most abundant fragment peaks in the mass spectra of OA at T1 (Fig. 10a), were very similar (Fig. 6c). Both $m / z$ 's were mainly contributed by oxygenated organic ions (Fig. 10a). The $\mathrm{C}_{2} \mathrm{H}_{3} \mathrm{O}^{+}$ion, which is commonly associated with aldehydes or ketones ( $\mathrm{Ng}$ et al., 2011a), represented $86 \%$ of the signal at $\mathrm{m} / z 43$ (Org43). The $\mathrm{CO}_{2}^{+}$ion, which is associated with carboxylic acids (Alfarra, 2004; Takegawa et al., 2007), accounted for $96 \%$ of the organic signal at $\mathrm{m} / \mathrm{z} 44$ (Org44). These results indicate that condensation of low volatility oxygenated species formed from gas-phase reactions was the major formation mechanism for particulate organics at $\mathrm{T} 1$.

\subsubsection{Temporal and diurnal variations and implications of aerosol sources and processes at $\mathrm{T} 1$}

The concentration, chemical composition and size distribution of $\mathrm{PM}_{1}$ varied dynamically throughout this study (Fig. 2), revealing the influences of various sources and processes. Organics were the dominant species during the entire study, except during periods of very low $\mathrm{PM}_{1}$ loading $\left(<1 \mu \mathrm{g} \mathrm{m}^{-3}\right)$ when the mass fraction of sulfate increased to up to $50 \%$ of total $\mathrm{PM}_{1}$ (Figs. 6a and 5d). The fact that sulfate dominated aerosol composition in clean air masses (Fig. 5d), which was mainly associated with northwesterly flow, suggests a regional source of this species. This is consistent with the larger size distribution of sulfate compared to that of organics (Figs. $6 \mathrm{~b}$ and 7 , right panel). On the other hand, periods with high $\mathrm{PM}_{1}$ loading were associated with high mass fraction of oxidized organics (Fig. 5d), indicating that episodes of aerosol pollution over the Sierra Nevada foothills were mainly driven by SOA formation (detailed discussions are given in Sect. 3.2). A gradual increase of particle concentration from 1.5 to $11 \mu \mathrm{g} \mathrm{m}^{-3}$ was observed between 20 and 28 June 2010 (Fig. 2a). The increase was mainly contributed by organics and was accompanied with sharp increases in isoprene concentrations, especially during the last 4 days of the campaign (Fig. S1 in the Supplement). Since both maximum $\mathrm{O}_{3}$ mixing ratios (in the range $70-80 \mathrm{ppb}$; Fig. S1c in the Supplement) and highest daily average temperature also occurred during those days, the increase of aerosol concentration was likely due to more intense chemical processing of aerosol and gas phase pollutants in the region. 

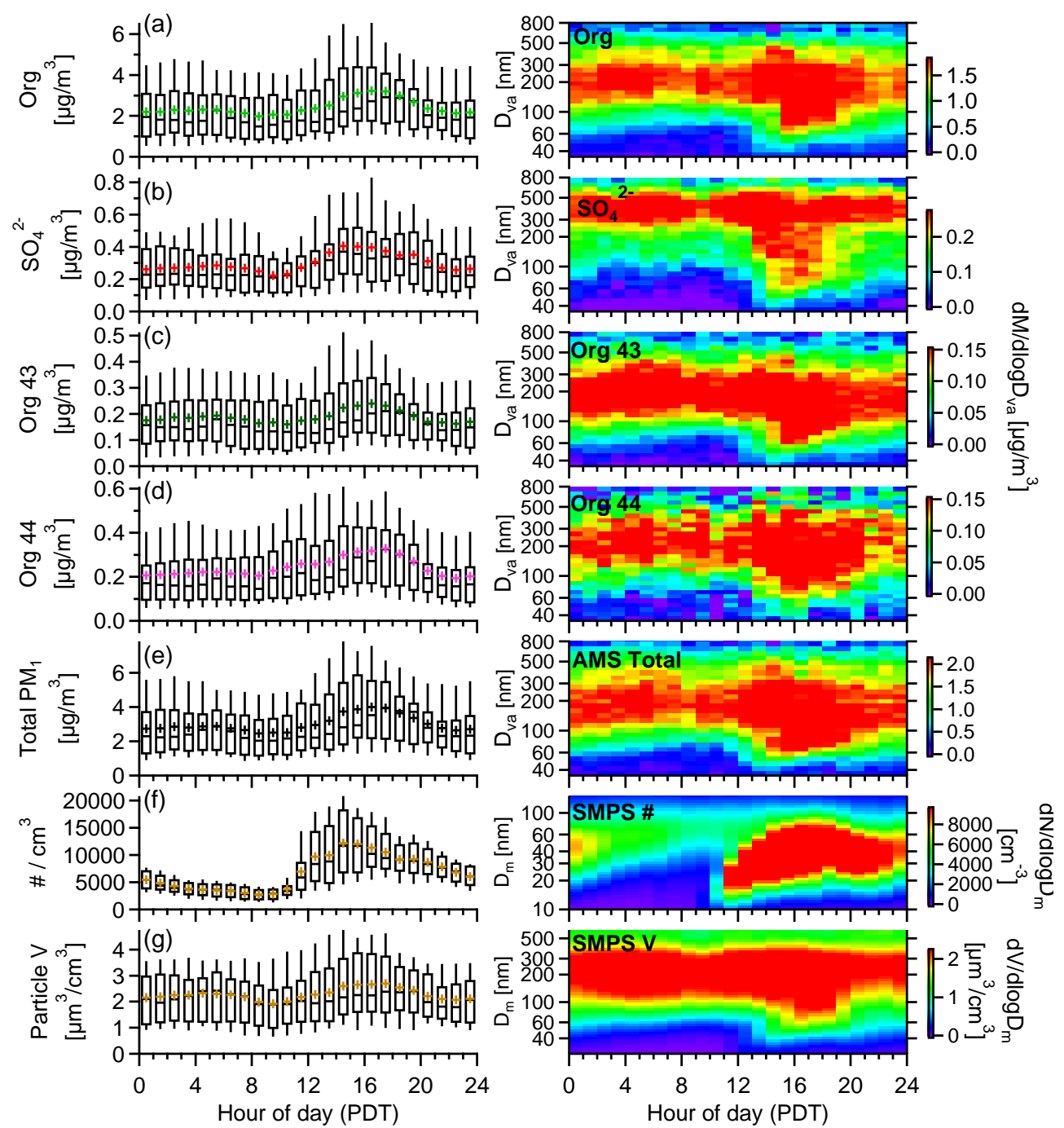

Fig. 7. Diurnal patterns (left panel) and diurnal size distributions (right panel) of (a) organics, (b) sulfate, (c) Org 43, (d) Org 44, (e) AMS total mass, (f) particle number, and (g) volume concentrations. Box plots: whiskers correspond to the 10th and 90th percentile, boxes to the 25th and 75th percentile, the horizontal marks in the boxes to the median, and the colored crosses to the mean.

The concentrations and size distributions of the chemical species in $\mathrm{PM}_{1}$ all showed strong diurnal variations (Fig. 7), which were mainly driven by the very consistent wind patterns as well as the formation of secondary aerosols. Specifically, organics, sulfate, and particle number concentrations all began to increase at $\sim 10: 00$ and peaked between 15:00-17:00 (Fig. 7). This time period corresponds to the downwind transport from Sacramento to Cool (i.e., $\mathrm{T} 0$ to $\mathrm{T} 1$ transport) coupled to photochemical oxidation. Indeed, using a Lagrangian particle dispersion model system, Fast et al. (2012) determined that the transport times between Sacramento and Cool range between $2-8 \mathrm{~h}$ on days with southwesterly winds and that the peak surface concentrations of air pollutants at Cool on average occur around 17:00 PDT in June. Furthermore, the diurnal profile of ozone mixing ratio at $\mathrm{T} 1$ demonstrated a peak between
16:00-17:00 (Fig. 8) because of southwesterly winds that transported ozone produced in Sacramento over the Sierra coupled with additional daytime photochemical production downwind of Sacramento. Similarly, the daytime increase of organics lasted till $\sim$ 17:00 as well, contributed by the transport and subsequent oxidation of VOC precursors emitted from both anthropogenic (from the Sacramento area) and biogenic (from the vegetation between Sacramento and the foothills) sources. The increase of sulfate (mainly in particles smaller than $200 \mathrm{~nm}$ in $D_{\text {va }}$, Fig. 9b) in the afternoon can be explained by the transport of $\mathrm{SO}_{2}$ from upwind sources, e.g., the refineries located in the Bay Area (Fig. 1a), coupled with photochemical oxidation and condensation of low volatility products.

A slight increase of organics and sulfate, primarily in particles smaller than $300 \mathrm{~nm}\left(D_{\mathrm{va}}\right)$, occurred at night, starting 


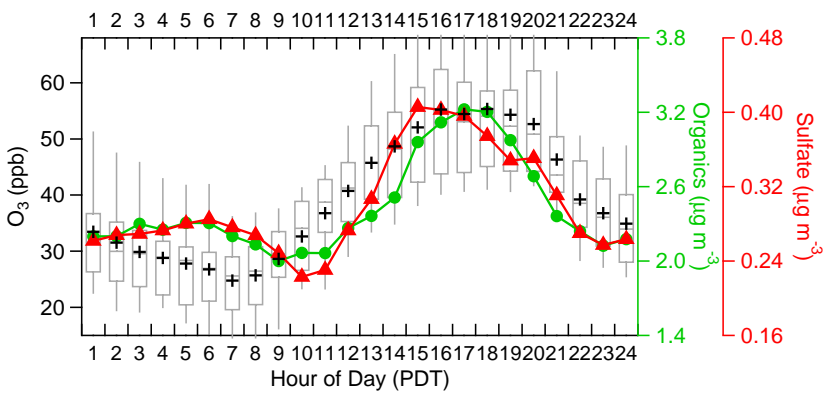

Fig. 8. Diurnal patterns of $\mathrm{O}_{3}$, organics and sulfate. Box plots for $\mathrm{O}_{3}$ : whiskers correspond to the 10th and 90th percentile, boxes to the 25 th and 75 th percentile, the horizontal marks in the boxes to the median, and the black crosses to the mean. Data for organics and sulfate correspond to the mean.

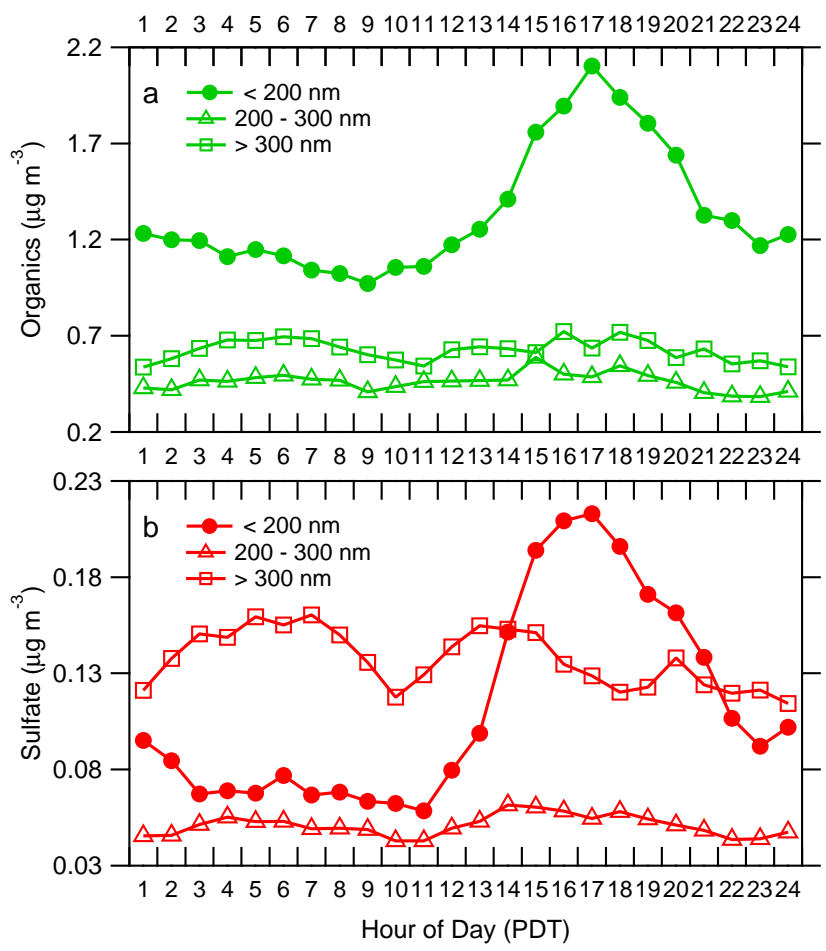

Fig. 9. Diurnal patterns of organics (a) and sulfate (b) in the size range $35-200 \mathrm{~nm}, 200-300 \mathrm{~nm}$ and $300-1000 \mathrm{~nm}$ (in $D_{\text {va }}$ ). Data correspond to the mean.

around 22:00 (Fig. 9). This time corresponds to nocturnal downslope flows (Fig. 1b), when a part of the polluted air transported to the Sierra Nevada during the day came back to the foothills. Model simulations coupled with observations made during CARES indeed showed that the nighttime recirculation could transport aged trace gases and aerosols from the western slopes of the Sierra Nevada back over Sacramento (Fast et al., 2012). In addition, a decrease of the boundary layer height, thus less dilution, together with continued reactions of biogenic VOCs with the nighttime residual ozone (20-35 ppb on average; Fig. 8) and other oxidants (e.g., nitrate radical) might have played a role in the increase of SOA species as well.

New particle formation (NPF) and growth events occurred almost every day during this study (Fig. 2d) and were frequently observed in the Sierra Nevada (Lunden et al., 2006; Creamean et al., 2011). In this study, the particle number concentration with sizes of $8-858 \mathrm{~nm}$ showed a sharp increase between $\sim 09: 00$ (2800 particles $\mathrm{cm}^{-3}$ ) and 15:00 (12 100 particles $\mathrm{cm}^{-3}$; Fig. 7f), accompanied by the simultaneous increases of organics and sulfate. However, the smallest size measured by our SMPS was $8 \mathrm{~nm}$ in mobility diameter $\left(D_{\mathrm{m}}\right)$ whereas new particles formed by nucleation have generally $1 \mathrm{~nm}$ diameter (Holmes, 2007). Given that the growth rate of new particles was on average $\sim 5 \mathrm{~nm} \mathrm{~h}^{-1}$ during this study, a lag time of $1-2 \mathrm{~h}$ is necessary between the formation and the growth of the new particles to a detectable size, and the onset of nucleation should have occurred earlier. Moreover, an additional lag of several hours is necessary for new particles to grow to sizes detectable by the AMS (minimum $35 \mathrm{~nm}$ in $D_{\text {va }}$, corresponding to $\sim 25 \mathrm{~nm}$ in $D_{\mathrm{m}}$ assuming spherical particles with a density of $1.4 \mathrm{~g} \mathrm{~cm}^{-3}$ ). An increase of the organics and sulfate concentrations in ultrafine particles was observed between 11:00 and 16:00 (Fig. 7, right panel). The average increase of the mass concentration of organics $\left(\sim 1.1 \mathrm{\mu g} \mathrm{m}^{-3}\right)$ was $\sim 6.5$ times higher than that of sulfate $\left(\sim 0.17 \mathrm{\mu g} \mathrm{m}^{-3}\right)$ between 10:00-17:00 (Fig. 8), indicating that organics played a more important role in new particle growth than sulfate did. We notice that the mass concentrations of both Org 43 (mainly $\mathrm{C}_{2} \mathrm{H}_{3} \mathrm{O}^{+}$) and Org 44 (mainly $\mathrm{CO}_{2}^{+}$) in the ultrafine mode increased during this period (Fig. 7c and d). Similarly, increases of Org 43 and 44 in the ultrafine mode were observed during the growth of new particles at Pittsburgh (Zhang et al., 2004; Zhang et al., 2005c) and in a Finnish Forest (Allan et al., 2006). Since the total increase of these two fragments alone $\left(0.2 \mu \mathrm{g} \mathrm{m}^{-3}\right)$ is as much as the increase of sulfate during the same period, oxidized organics appear to have played important roles in growing new particles in the Sierra Nevada foothills. A complete description and the determination of the conditions allowing the formation of new particles and their subsequent growth and the evolution of particle chemistry will be presented in a separate paper.

\subsubsection{Chemical properties of organics}

Organics, which dominated $\mathrm{PM}_{1}$ composition at $\mathrm{T} 1$, were overall oxidized with average $\mathrm{O} / \mathrm{C}=0.44$ (range $0.06-0.75$ ) and $\mathrm{H} / \mathrm{C}=1.38$ (range 1.01-2.09). The nominal formula of organics at $\mathrm{T} 1$ during CARES was $\mathrm{C}_{1} \mathrm{H}_{1.38} \mathrm{~N}_{0.004} \mathrm{O}_{0.44}$, which corresponds to an average organic mass-to-carbon $(\mathrm{OM} / \mathrm{OC})$ ratio of 1.70 (range 1.19-2.15). As shown in Fig. 10a, the average organic mass spectrum was dominated by four oxygenated ions: $\mathrm{CO}_{2}^{+}(\mathrm{m} / \mathrm{z} 44), \mathrm{CO}^{+}(\mathrm{m} / \mathrm{z}, 28)$, $\mathrm{C}_{2} \mathrm{H}_{3} \mathrm{O}^{+}(\mathrm{m} / \mathrm{z}, 43)$, and $\mathrm{CHO}^{+}(\mathrm{m} / \mathrm{z}, 29)$. In addition, $55 \%$ of the signal at $\mathrm{m} / \mathrm{z} 57$ was contributed by an oxygenated 


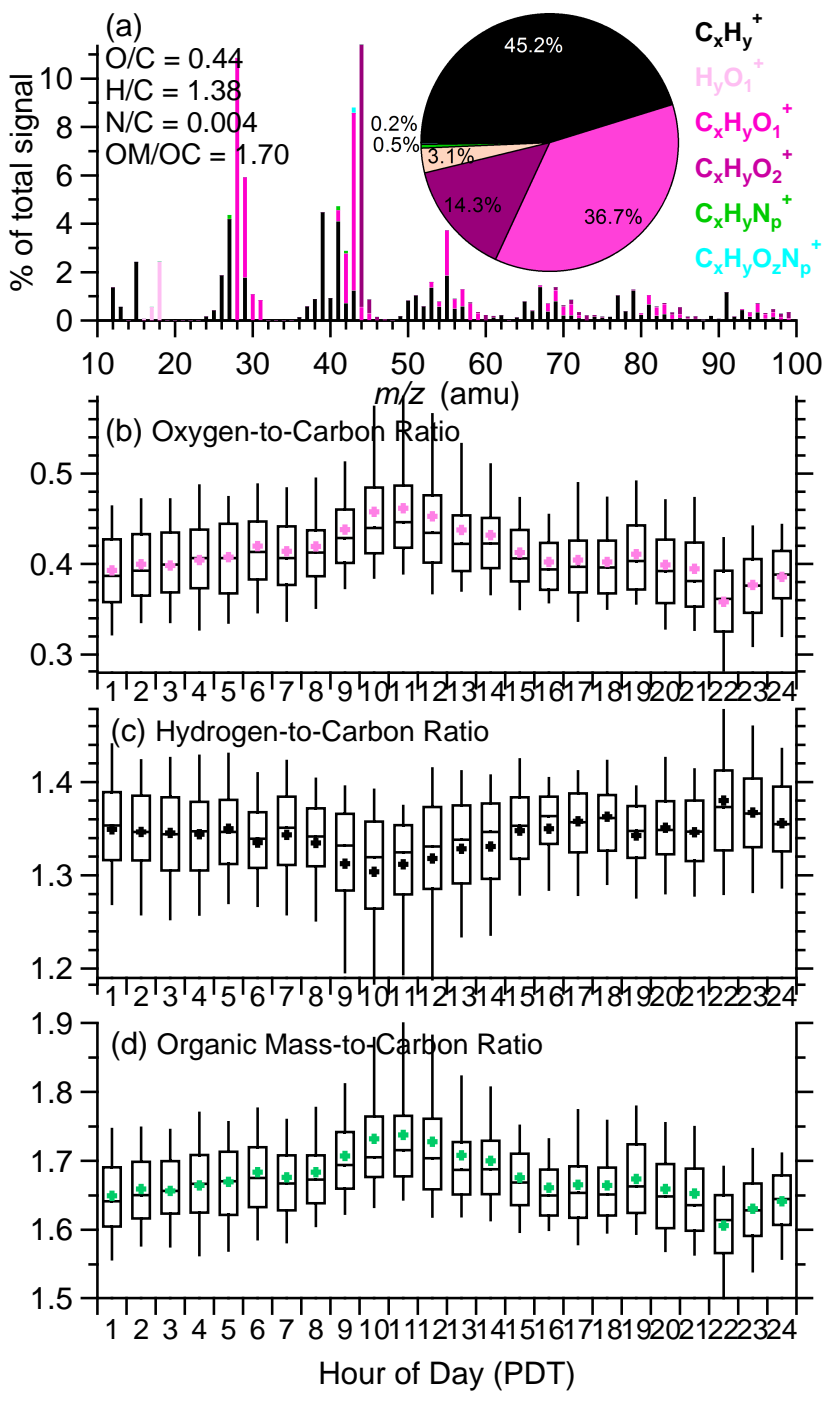

Fig. 10. (a) Average high resolution mass spectrum of organics colored by ion category, along with a pie chart with the contribution of each ion category to the total signal. Diurnal patterns of (b) oxygen-to-carbon $(\mathrm{O} / \mathrm{C})$ ratio, (c) hydrogen-to-carbon $(\mathrm{H} / \mathrm{C})$ ratio, and (d) organic mass-to-carbon (OM/OC) ratio of organics. The $\mathrm{C}_{\mathrm{x}} \mathrm{H}_{\mathrm{y}} \mathrm{S}_{n} \mathrm{O}_{\mathrm{z}}^{+}$family is not shown in the pie chart due to its very small contribution (average $=0.09 \%$ ). Box plots: whiskers correspond to the 10th and 90th percentile, boxes to the 25 th and 75 th percentile, the horizontal marks in the boxes to the median, and the colored crosses to the mean.

ion $-\mathrm{C}_{3} \mathrm{H}_{5} \mathrm{O}^{+} . \mathrm{C}_{4} \mathrm{H}_{9}^{+}$, which is a dominant ion at $\mathrm{m} / z 57$ in POA from fossil fuel combustion (Mohr et al., 2009) and has been used as an AMS tracer ion for HOA (e.g., Zhang et al., 2005a), accounts for $45 \%$ of the $\mathrm{m} / z 57$ and only $0.44 \%$ of the total organic signal, due to minor influence of primary emissions at $\mathrm{T} 1$.

The elemental ratios $(\mathrm{O} / \mathrm{C}$ and $\mathrm{H} / \mathrm{C})$ of the organics show strong diurnal patterns (Fig. 10b-d). O/C increased from 0.41 to 0.46 between $07: 00$ and 12:00 while $\mathrm{H} / \mathrm{C}$ decreased simul- taneously (Fig. 10b and c). Given that the observed increases of $\mathrm{O} / \mathrm{C}$ coincided with the increases of Org 43, Org 44, and total organics mass in particles smaller than $300 \mathrm{~nm}$ (Fig. 7c and d), daytime formation and condensation of low volatility and oxidized organics onto the surface of pre-exiting particles appeared to be an important mechanism controlling organic aerosol composition and loading in the Sierra foothills region. The slight decrease of $\mathrm{O} / \mathrm{C}$ and increase of $\mathrm{H} / \mathrm{C}$ between 21:00-22:00 were likely due to the emissions of primary hydrocarbon-like organic particles from local sources (Fig. 11k; see Sect. 3.2). Compared to OA observed at Whistler Mountain, a forested site in western Canada, the average $\mathrm{O} / \mathrm{C}$ ratio of this study was much lower ( 0.44 vs. 0.83 (Sun et al., 2009). A major reason is that Whistler peak is a frequent receptor of highly aged aerosols associated with trans-Pacific dust events and regional plumes (McKendry et al., 2008; Sun et al., 2009). In addition, aqueous-phase processing of aerosols in clouds, which could increase the O/C of organics (Ervens et al., 2011), is likely an important process given the frequent cloud cover over Whistler peak (Sun et al., 2009). In contrast, since the weather during CARES was mostly dry with sunny skies (Fast et al., 2012) the formation of SOA was primarily driven by gas-phase reactions and condensation of low volatility species. This conclusion is supported by the observation of a dominant condensation mode in the size distribution of organics throughout the entire study (Fig. 7a, right panel). Overall, the $\mathrm{O} / \mathrm{C}$ values observed at T1 suggest that organic particles over the Sierra foothill were less aged, comprising of SOA formed in urban plume during transport or locally from biogenic VOCs.

\subsection{Organic aerosol factors and discussions on the sources and processes affecting $O A$ composition}

Three distinct OA factors were identified for this study via PMF analysis of the high resolution mass spectra of organics. These include two oxygenated OA factors, one more oxidized $(\mathrm{O} / \mathrm{C}=0.54)$ than the other $(\mathrm{O} / \mathrm{C}=0.42)$, and a hydrocarbon-like $\mathrm{OA}(\mathrm{HOA}, \mathrm{O} / \mathrm{C}=0.08)$. A number of previous studies identified more than one OOA factors at various locations (e.g., Jimenez et al., 2009; Lanz et al., 2010; $\mathrm{Ng}$ et al., 2010; Zhang et al., 2011, and references therein). Based on correlations with sulfate and ammonium nitrate, OOAs are usually named based on their inferred volatilities, e.g., LV-OOA (low volatility) and SV-OOA (semi-volatile) (Jimenez et al., 2009). However, Hildebrandt et al. (2010) identified two OOA factors with similar volatility but different $\mathrm{O} / \mathrm{C}$ at a remote coastal site in Greece. For the present study, our preliminary analysis of the thermodenuder data indicates that both OOAs were more volatile than sulfate and that they showed somewhat different volatility profiles. But the differences did not appear statistically significant due to relatively noisy data. We thus use the terms of "more oxidized" (MO-OOA) and "less oxidized" OOA (LO-OOA) in the forthcoming discussions. 

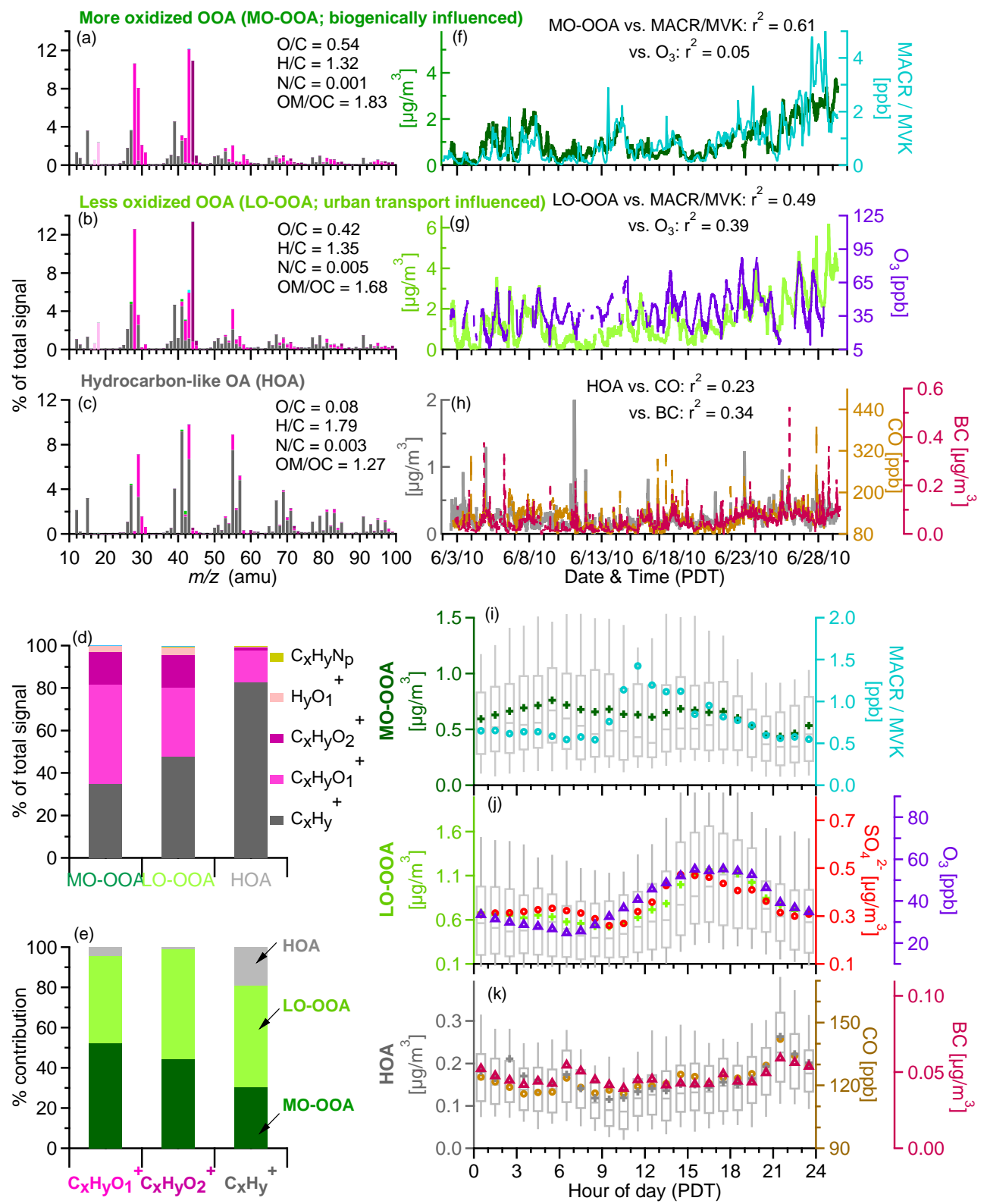

Fig. 11. High-resolution mass spectra (colored by ion category) and elemental ratios of the OA factors. Average contribution of ion categories to the total signal of the OA factors (d), and average contribution of OA factors to the three main ion categories (e). Time series (f, $\mathbf{g}, \mathbf{h})$ and diurnal patterns $(\mathbf{i}, \mathbf{j}, \mathbf{k})$ of OA factors and tracer compounds, along with their correlation coefficients $\left(r^{2}\right)$. Grey box plots for OA factors $(\mathbf{i}, \mathbf{j}, \mathbf{k})$ : whiskers correspond to the 10th and 90th percentile, boxes to the 25th and 75th percentile, the horizontal marks in the boxes to the median, and the colored solid circles to the mean. Colored markers for tracer compounds $(\mathbf{i}, \mathbf{j}, \mathbf{k})$ correspond to the mean.

\subsubsection{More oxidized OOA (MO-OOA) and association with biogenic emissions}

As shown in Fig. 11a, the mass spectrum of MO-OOA is dominated by oxygenated fragments (i.e., ions from the $\mathrm{C}_{\mathrm{x}} \mathrm{H}_{\mathrm{y}} \mathrm{O}_{1}^{+}$and $\mathrm{C}_{\mathrm{x}} \mathrm{H}_{\mathrm{y}} \mathrm{O}_{2}^{+}$families). $\mathrm{m} / \mathrm{z} 43(97.4 \%$ is $\left.\mathrm{C}_{2} \mathrm{H}_{3} \mathrm{O}^{+}\right)$and $m / z \quad 44\left(97.3 \%\right.$ is $\left.\mathrm{CO}_{2}^{+}\right)$were the largest peaks. The $\mathrm{O} / \mathrm{C}$ ratio (0.54) in MO-OOA falls between the average values observed in the SV-OOA $(0.35 \pm 0.14)$ and LV-OOA $(0.73 \pm 0.14)$ factors identified in worldwide datasets (Jimenez et al., 2009; $\mathrm{Ng}$ et al., 2010). The O/C ratio and the mass spectrum of MO-OOA are similar to those of biogenic SOA (BSOA) acquired from chamber studies and ambient environments. A few prominent ions measured in BSOA, such as $\mathrm{C}_{2} \mathrm{H}_{3} \mathrm{O}^{+}(\mathrm{m} / \mathrm{z}, 43)$ and $\mathrm{C}_{3} \mathrm{H}_{6} \mathrm{O}^{+}(\mathrm{m} / \mathrm{z}, 58)$ (Chen et al., 2009; Kiendler-Scharr et al., 2009; Slowik et al., 2010), are also enhanced in MO-OOA, accounting for $12 \%$ and $1.1 \%$, respectively, of the total signal. In addition, 
the signal of $\mathrm{CHO}^{+}(\mathrm{m} / \mathrm{z}, 29)$ is clearly enhanced in the MOOOA spectrum compared to that in the average OOA mass spectrum of different field campaigns ( $\mathrm{Ng}$ et al., 2011b), but in similar abundance as it is in the spectra of $\alpha$-pinene and isoprene SOAs from smog chamber experiments (Alfarra et al., 2006; Shilling et al., 2009; Chhabra et al., 2010), BSOAs from plant chamber experiments (Kiendler-Scharr et al., 2009), and ambient OOAs influenced by biogenic emissions (Chen et al., 2009; Kiendler-Scharr et al., 2009; Slowik et al., 2010). Note that previous studies have reported significant signals at $\mathrm{m} / \mathrm{z} 29$ in the spectra of biomass burning particles ( $\mathrm{Ng}$ et al., 2011b). However, in the absence of signals at $m / z 60\left(\mathrm{C}_{2} \mathrm{H}_{4} \mathrm{O}_{2}^{+}\right)$and $73\left(\mathrm{C}_{3} \mathrm{H}_{5} \mathrm{O}_{2}^{+}\right)$, which correspond to the two fragments of levoglucosan usually used as tracers for biomass burning, the signal at $\mathrm{m} / \mathrm{z} 29$ cannot be associated to biomass burning in this study. As shown in Fig. S7, the agreements between the mass spectra of our MO-OOA vs. biogenic SOA identified at Chebogue Point $\left(r^{2}=0.95\right)$ and from plant chamber experiments $\left(r^{2}=0.97\right.$; Kiendler-Scharr et al., 2009) are especially high. Since the AMS ionizes molecules with $70 \mathrm{eV}$ electrons, the mass spectrum it generates for an ensemble aerosol should reflect its bulk chemical composition (McLafferty and Turecek, 1993; Canagaratna et al., 2007). The observed mass spectral similarities thus suggest a compositional resemblance between MO-OOA and biogenic SOA.

Another support for associating MO-OOA with BSOA is the temporal variation profiles of aerosol and gaseous species observed during this study. MO-OOA showed very weak correlation with primary emission tracers for anthropogenic sources (e.g., BC, $\mathrm{CO}$, benzene, toluene, and aromatic hydrocarbon derivatives; $r^{2}<0.2$ ). It, however, correlated moderately with biogenic VOCs (isoprene and monoterpenes; $r^{2}$ of $\left.0.3-0.4\right)$ and fairly well with two isoprene oxidation products - methacrolein (MACR) and methyl vinyl ketone $(\mathrm{MVK})\left(r^{2}=0.61\right.$; Fig. S8a). The covariance between MO-OOA and MACR/MVK was particularly high during several periods in the first three weeks of the study (Fig. 11f). Both MO-OOA and MACR/MVK increased during last week of the campaign due to enhanced photochemical processing, but the increase of MACR/MVK was much greater (Fig. 11f), weakening the overall linear relationship between them (Fig. S8a). MO-OOA also correlated well with two long-lived oxygenated VOCs - acetone $\left(r^{2}=0.73\right)$ and methanol $\left(r^{2}=0.61\right)$. According to previous reports vegetation is a main source of atmospheric methanol (Jacob et al., 2005) whereas acetone is generated in part through atmospheric oxidation of precursor hydrocarbons in addition to plant emissions (Jacob et al., 2002). During this study, these two VOCs covaried tightly $\left(r^{2}=0.87\right.$; Fig. S11 in the Supplement), which was also the case during two previous field campaigns at the Blodgett Forest (Schade and Goldstein, 2001, 2006). The strong correlation suggests that both compounds were mainly associated with biogenic sources at the Sierra foothills. All these results corroborate the notion that MO-OOA was associated with photochemical processing of biogenic precursors.

Despite positive correlation, MO-OOA and MACR/MVK had quite different diurnal patterns (Fig. 11i). MACR/MVK increased sharply in the morning and declined shortly past noon, whereas the diurnal profile of MO-OOA was relatively flat but showed two small increases in the early afternoon (peak around 14:00) and at night from 22:00 to 05:00 (Fig. 11i). The daytime increase happened during the strong midday emission of isoprene from the surrounding deciduous forest due to elevated temperature and light intensity (Sharkey et al., 1996), coupled with the simultaneous peaking of photochemical oxidants (e.g., OH). The nighttime increase likely corresponded to the nocturnal downslope winds which transport air masses over the Sierra Mountains back to the foothills (Fast et al., 2012). Indeed, a close look at the time series of the PTR/MS data (Fig. S1 in the Supplement) reveals that amongst all the VOCs recorded at T1, only monoterpenes showed an important increase during the night. In fact, the concentrations of monoterpenes reached a peak between 05:00 and 06:00 and decreased very fast during the day. This behavior may arise because (1) pine trees which emit monoterpenes grow mostly on the east of the T1 site, at higher elevations of the Sierra Nevada and (2) the regular nocturnal downslope flows bring emissions in the Sierras back to the foothills (Fast et al., 2012). The fast daytime decrease of monoterpenes may be due to the high reactivity of these compounds as well as the scarcity of pine trees to the southwest of T1. In addition, the peaking of MO-OOA later than the peaking of MACR/MVK is consistent with the facts that MACR and MVK are the first generation oxidation products of isoprene and that they undergo further reactions to produce SOA. This explanation is confirmed by previous chamber experiments on isoprene photooxidation, in which the production of SOA was found to occur at the same time as the oxidation of the primary oxidation products (e.g., MACR+MVK) and the increase of SOA continued for several hours after MACR/MVK reached maximum (Lee et al., 2006; Holzinger et al., 2007). It is also important to point out that since the formation of MVK and MACR from isoprene oxidation occurs on a time scale of several hours (Apel et al., 2002), the fact that MO-OOA covaried with them suggests that a large fraction of the biogenic SOA over the Sierra foothills was relatively fresh with an average photochemical age of several hours.

\subsubsection{Less oxidized OOA (LO-OOA) and association with anthropogenic emissions}

Similar to MO-OOA, oxygenated fragments dominate the LO-OOA mass spectrum, in which $m / z, 44\left(94 \%\right.$ is $\left.\mathrm{CO}_{2}^{+}\right)$is the most abundant peak. However, the $\mathrm{C}_{\mathrm{x}} \mathrm{H}_{\mathrm{y}}^{+}$ions are more important in LO-OOA (Fig. 11b), accounting for $48 \%$ of the total signal (vs. $35 \%$ in MO-OOA; Fig. 11d). It was observed previously that when organic particles become more 


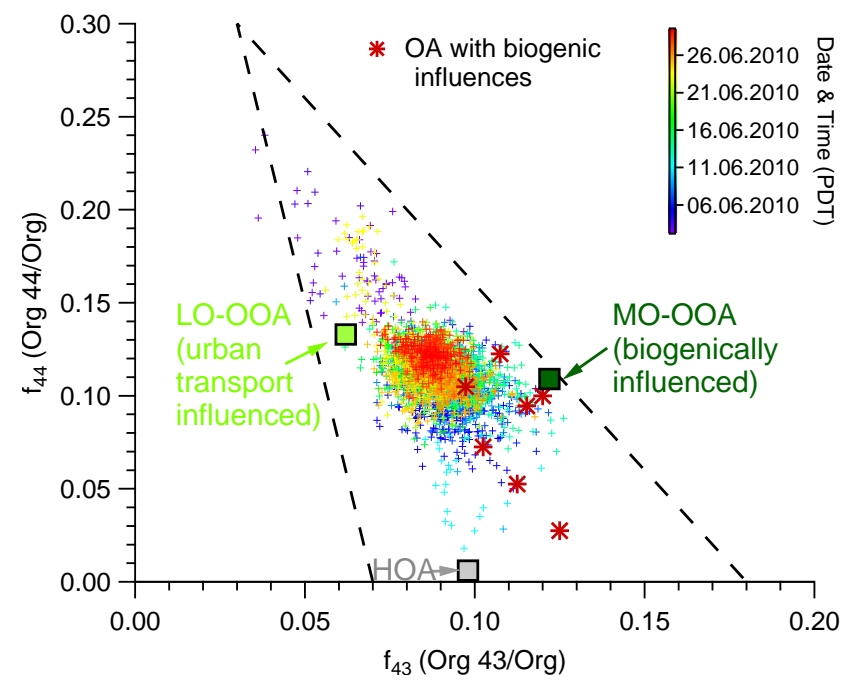

Fig. 12. Triangle plot $\left(f_{44}\right.$ vs. $\left.f_{43}\right)$ with ambient data (colored by time) and OA factors determined via PMF analysis of the high resolution organic mass spectra. The triangle region was determined by $\mathrm{Ng}$ et al. (2010) and corresponds to region where ambient OOA factors from different datasets fall. Dark red star points correspond to OOA factors previously published and reporting biogenic influences (Allan et al., 2006; Williams et al., 2007; Cottrell et al., 2008; Kiendler-Scharr et al., 2009; Sun et al., 2009; Raatikainen et al., 2010; Slowik et al., 2010).

oxidized, $\mathrm{f}_{44}$ (the fraction of total mass spectral signal at $\mathrm{m} / \mathrm{z}, 44$ ) and $\mathrm{O} / \mathrm{C}$ increase together (Aiken et al., 2008; $\mathrm{Ng}$ et al., 2010). However, in the present study, despite larger $\mathrm{f}_{44}$ in LO-OOA than in MO-OOA, the $\mathrm{O} / \mathrm{C}$ in LO-OOA is lower than in MO-OOA (0.42 vs. 0.54; Fig. 11a and b). This divergence was because the $\mathrm{O} / \mathrm{C}$ ratio depends not only on the relative abundance of the $\mathrm{m} / \mathrm{z} 44$ fragment (mostly $\mathrm{CO}_{2}^{+}$) but also on hundreds of other ions containing carbon and oxygen. Thus, $\mathrm{f}_{44}$ alone is unable to predict the $\mathrm{O} / \mathrm{C}$ value accurately if ions other than $\mathrm{CO}_{2}^{+}$contribute substantially to overall $\mathrm{O} / \mathrm{C}$ (Chhabra et al., 2010). Indeed, $\mathrm{CHO}^{+}(\mathrm{m} / \mathrm{z}, 29)$ accounts for $7.6 \%$ of the total signal in the MO-OOA spectrum, compared to $1.0 \%$ in LO-OOA. The large $\mathrm{CHO}^{+}$peak increases the $\mathrm{O} / \mathrm{C}$ of MO-OOA. Meanwhile, a bigger fraction of $\mathrm{C}_{\mathrm{x}} \mathrm{H}_{\mathrm{y}}^{+}$in LO-OOA decreases its $\mathrm{O} / \mathrm{C}$.

The mass spectral differences between LO-OOA and MOOOA (Fig. 11a and b) imply significant differences in their chemical compositions. A main spectral difference is highlighted in Fig. 12, which shows $\mathrm{f}_{44}$ vs. $\mathrm{f}_{43}$ for the three OA factors and ambient data acquired during this study. $\mathrm{f}_{44}$ and $\mathrm{f}_{43}$ denote the fractions of the total signal at $\mathrm{m} / \mathrm{z}, 44$ and $\mathrm{m} / \mathrm{z}, 43$ in a mass spectrum. This triangle plot, first presented by $\mathrm{Ng}$ et al. (2010), is a practical way of classifying OOA factors identified in different atmospheric environments. Factors with different levels of oxidation fall in different regions of the triangle plot. The more oxidized, low volatility OOAs usually fall in the upper part of the triangle, whereas the less oxidized semivolatile OOAs fall in the lower part. The region corresponding to SV-OOA is broad, which indicates that fresher OOAs may have more variable mass spectra, depending on their sources and processes. The upper part of the triangle is much thinner, suggesting that SOA composition tends to become more similar after ageing and long oxidation processes ( $\mathrm{Ng}$ et al., 2010).

Both OOAs of this study reside in the middle region of the triangle where the less oxidized SV-OOAs and the more aged LV-OOAs overlap (Fig. 12). However, LO-OOA lies near the left side of the triangle whereas MO-OOA lies near the right side. Most interestingly, the $\mathrm{f}_{43}(0.12)$ and the $\mathrm{f}_{44} / \mathrm{f}_{43}$ ratio (0.9) of MO-OOA are within the range of the corresponding values observed for ambient OOAs influenced significantly by biogenic emissions (Allan et al., 2006; Cottrell et al., 2008; Chen et al., 2009; Kiendler-Scharr et al., 2009; Sun et al., 2009; Raatikainen et al., 2010; Slowik et al., 2010). These observations reinforce our arguments that the MO-OOA factor of this study represents biogenic SOA (see discussions in Sect. 3.2.1). However, it is important to note that the "position" of an OOA factor in the triangle plot is not a reliable indicator for its sources. For example, the mass spectra of chamber SOAs generated from anthropogenic hydrocarbons were found to be highly variable (Chhabra et al., 2011; Lambe et al., 2011). While SOAs from alkanes, polycyclic aromatic hydrocarbons (PAHs), and lubricating oil generally lie on the left region of the triangle plot, closer to LOOOA than to MO-OOA, SOAs produced from diesel fuel, mxylene, and toluene lie on the right side of triangle (Chhabra et al., 2011; Lambe et al., 2011), overlapping with SOAs from biogenic precursors and MO-OOA. Nevertheless, given the very low mixing ratios of aromatic VOCs (e.g., average concentration of benzene + toluene was $0.12 \mathrm{ppb}$; Fig. S1 in the Supplement), especially compared to the very high concentrations of isoprene (1.2 ppb) observed during this study, it is unlikely that aromatic compounds contributed significantly to SOA production over the Sierra foothills.

In addition to mass spectral differences, the temporal profiles of LO-OOA and MO-OOA were different from each other as well, suggesting that they were influenced by different emission sources or atmospheric processes. LO-OOA correlated positively with ozone $\left(r^{2}=0.39\right.$; Figs. $11 \mathrm{~g}$ and $\mathrm{S} 8 \mathrm{~b}$ ) and both showed a prominent diurnal cycle (Fig. 11j). In contrast, there was almost no correlation between MOOOA and $\mathrm{O}_{3}\left(r^{2}=0.05\right)$ and their diurnal patterns were obviously different. Herndon et al. (2008) observed a strong correlation between OOA and odd oxygen $\left(\mathrm{O}_{\mathrm{x}}=\mathrm{O}_{3}+\mathrm{NO}_{2}\right)$ in photochemically processed urban plumes from Mexico City. This observation was made at a downwind site free of local emission sources and meteorological transport was found responsible for the correlation between $\mathrm{OOA}$ and $\mathrm{O}_{3}$ (Herndon et al., 2008; Wood et al., 2010). For the present study, due to the lack of $\mathrm{NO}_{2}$ data, we did not use odd oxygen but just $\mathrm{O}_{3}$. Nevertheless, our findings are very similar to those from Mexico City. As shown in Fig. 11j, LO-OOA 
correlated with ozone particularly well between 10:00 and 18:00 when photochemical processing was intense. The correlation between LO-OOA and $\mathrm{O}_{3}$ over the entire study appeared only moderate $\left(r^{2}=0.39\right.$; Fig. $\left.11 \mathrm{~g}\right)$ though, mainly because the linear relationships between them varied considerably from day to day (Fig. S8b in the Supplement). The strong correlation between LO-OOA and $\mathrm{O}_{3}-$ a secondary photochemical oxidant - during daytime indicates that LOOOA corresponded to photochemically produced SOA. The strong correlation also means that LO-OOA and $\mathrm{O}_{3}$ were formed on similar timescales, indicating that LO-OOA was relatively fresh, likely less than $8 \mathrm{~h}$ in photochemical age. A similar conclusion was reached about the OOA that correlated with $\mathrm{O}_{\mathrm{x}}$ in emission plumes from Mexico City (Wood et al., 2010). The relatively low $\mathrm{O} / \mathrm{C}(0.42)$ of LO-OOA is also consistent with its being relatively fresh.

The diurnal profiles of LO-OOA, $\mathrm{O}_{3}$, and sulfate were similar, showing strong increases between 10:00 to 18:00 (Fig. 11j). This time period corresponded to southwesterly upslope winds that regularly transport urban emissions from Sacramento over the foothills of the Sierra Nevada (Fast et al., 2012). In addition, the trends of LO-OOA, $\mathrm{O}_{3}$, and sulfate mirrored the daytime evolution patterns of aerosol number and size distributions, which were attributed to meteorological transport coupled to photochemical processing (Figs. 79; see discussion in Sect. 3.1.3). These results, together with the mass spectral features of LO-OOA (e.g., high contribution of ions from the $\mathrm{C}_{\mathrm{x}} \mathrm{H}_{\mathrm{y}}^{+}$family), indicated that LO-OOA corresponded to SOA photochemically produced in urban plumes that were transported to the Sierra foothills by southwesterly wind (Fast et al., 2012).

\subsubsection{HOA and association with local traffic emissions}

The HOA mass spectrum (Fig. 11c) shows characteristic signals of $\mathrm{C}_{4} \mathrm{H}_{9}^{+}(\mathrm{m} / \mathrm{z} 57), \mathrm{C}_{4} \mathrm{H}_{7}^{+}(\mathrm{m} / \mathrm{z}, 55)$, and hydrocarbon ion series increasing at $14\left(\mathrm{CH}_{2}\right)$ mass unit intervals (i.e., $\mathrm{C}_{n} \mathrm{H}_{2 n-1}^{+}$and $\left.\mathrm{C}_{n} \mathrm{H}_{2 n+1}^{+}\right) . \mathrm{C}_{\mathrm{x}} \mathrm{H}_{\mathrm{y}}^{+}$ions account for $83 \%$ of the total signal in HOA (Fig. 11d). The larger $\mathrm{C}_{n} \mathrm{H}_{2 n+1}^{+}(n>2)$ ions are mostly contributed by HOA, thus correlate tightly with HOA but poorly with the two OOAs (Fig. S8 in the Supplement). A similar behavior was observed in a summer study in New York City where the HOA factor was proven a surrogate for traffic-related POA (Sun et al., 2011). HOA is clearly separated from the two OOAs on the triangle plot (Fig. 12), indicating their chemical differences. However since the HOA spectrum also shows a major peak at $\mathrm{m} / \mathrm{z} 43$ (mostly $\mathrm{C}_{3} \mathrm{H}_{7}^{+}$), a second triangle plot corresponding to $\mathrm{f}_{\mathrm{CO}_{2}}$ $\left(\mathrm{CO}_{2}^{+}\right.$/total organic ratio) vs. $\mathrm{f}_{2} \mathrm{H}_{3} \mathrm{O}\left(\mathrm{C}_{2} \mathrm{H}_{3} \mathrm{O}^{+} /\right.$total organic ratio) is given in Fig. S10 in the Supplement to distinguish OA factors better. The mass spectrum pattern as well as the elemental ratios $(\mathrm{O} / \mathrm{C}=0.08, \mathrm{H} / \mathrm{C}=1.79)$ of the $\mathrm{HOA}$ factor identified in this study are consistent with the HOA factors representative of traffic emission determined in urban areas (e.g., Zhang et al., 2005c; Aiken et al., 2009; Allan et al., 2010; Sun et al., 2011; Ng et al., 2011b).

The average concentration of HOA was $0.22 \mu \mathrm{g} \mathrm{m}^{-3}$, which accounted for $9 \%$ of total OA mass over the entire campaign (Table 1). The sporadic spikes in HOA (Fig. 11h $\& 11 \mathrm{k}$ ) were probably due to local traffic around the sampling site. Note that because of low concentrations, the HOA and $\mathrm{BC}$ data were noisy, and the correlations between $\mathrm{HOA}$ and primary combustion tracers (BC and $\mathrm{CO}$ ) appeared to be relatively low $\left(r^{2}=0.34\right.$ and 0.23 , respectively; Figs. $11 \mathrm{~h}$, S8c, and S8d in the Supplement). For the same reason, the correlation between $\mathrm{CO}$ and $\mathrm{BC}$ was low during this study as well $\left(r^{2}=0.31\right)$. Similar observation was made at a rural site impacted by urban outflow where the correlations between HOA, BC, and CO were degraded because of noisy data (Zhang et al., 2007a). Note that oxidation of biogenic VOCs was unlikely a significant source of $\mathrm{CO}$ at $\mathrm{T} 1$. According to a previous study at Blodgett Forest, oxidation of biogenic VOCs was estimated to contribute only up to $5 \mathrm{ppb}$ of CO during summertime over the Sierra foothills (Worton et al., 2011). In addition, biomass burning was found negligible during this study as well (see discussions in Sect. 3.1.1). These results indicate that emissions related to transport were likely the main sources of HOA, CO, and BC at T1. Indeed, the diurnal patterns of these three species were very similar and all showed small increases between 6:00-7:00 and 21:00-22:00, probably due to local traffic near the sampling site (Fig. 11k). Furthermore, the average ratio of HOA/CO (after subtracting a background of $80 \mathrm{ppb}$ ) was determined at $\sim 5 \mathrm{\mu} \mathrm{m}^{-3} \mathrm{ppm}^{-1}$, which is very close to the HOA to $\mathrm{CO}$ emission ratios observed in urban plumes (Zhang et al., 2005c). These results, as well as its mass spectral pattern, indicate that the HOA factor determined in this study mainly represented POA emitted from transport related sources.

\subsection{Influence of anthropogenic emissions on SOA formation}

During this study, the average concentrations of LO-OOA and MO-OOA were $1.2 \mu \mathrm{g} \mathrm{m}^{-3}$ and $0.97 \mu \mathrm{g} \mathrm{m}^{-3}$, respectively (Table 1), which together accounted for $91 \%$ of the total organic mass and $72 \%$ of the $\mathrm{PM}_{1}$ mass (Table 1). Similarly, organics were found predominantly oxygenated during the BEARPEX 2007 field campaign (Worton et al., 2011), suggesting that SOA is a dominant aerosol component over the higher elevations of the Sierra Nevada as well. These observations indicate that SOA formation from both biogenic and anthropogenic precursors plays important roles controlling the loading, composition, and possibly climate-relevant properties of aerosols over the Sacramento and west Sierra Nevada region. Here, we compared aerosol concentrations, compositions, and size distributions during periods of urban plumes to those dominated by biogenic emissions (Table 1 and Fig. 13) to study the influence of anthropogenic emissions from Sacramento on the formation of SOA at the Sierra 


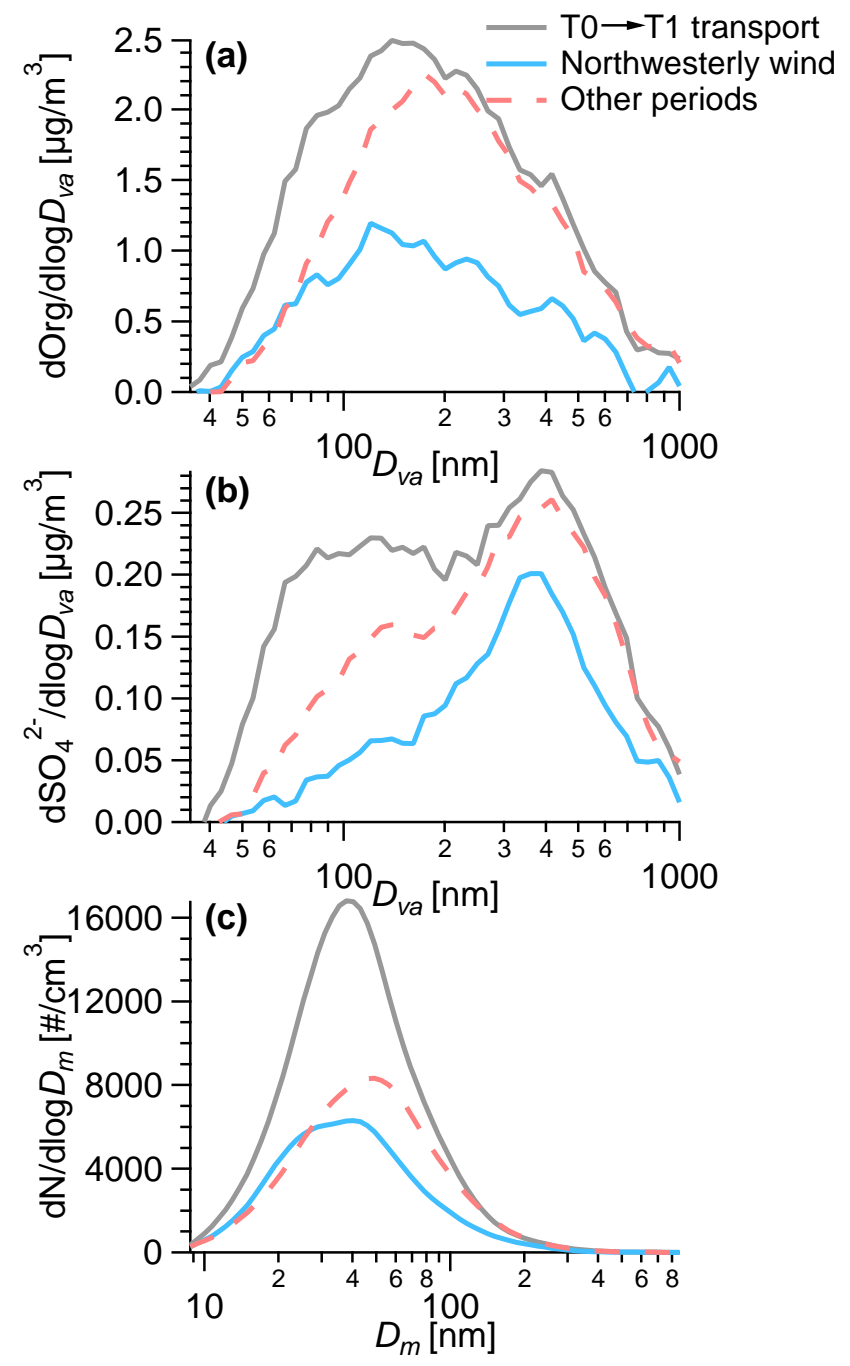

Fig. 13. Comparison of the average size distributions of (a) organics, (b) sulfate and (c) particle number concentration between the three air mass categories as marked on Fig. 2.

foothills, Details on the classification of the three types of air masses ( $\mathrm{T} 0 \rightarrow \mathrm{T} 1$ transport, northwesterly wind periods, and other periods) are given in Sect. 2.4. The average particle mass concentration was more than two times higher in urban plumes $\left(3.9 \mathrm{\mu g} \mathrm{m}^{-3}\right)$ than in background air (i.e., during the northwesterly wind period; $1.8 \mu \mathrm{g} \mathrm{m}^{-3}$ ). The mass distributions of two OOAs were consistent with different wind patterns, with urban plumes dominated by LO-OOA (i.e., urban transport SOA) and the northwesterly wind periods dominated by MO-OOA (i.e., biogenic SOA). The other periods were also dominated by the LO-OOA, likely because these periods correspond mainly to nocturnal downslope flows, which brought back a part of the polluted air from the Sierra Nevada to the foothills (also see discussions in Sect. 2.4). The average size distributions of organics and sulfate showed a significant difference between the three types of air masses - the presence of a mode smaller than $150 \mathrm{~nm}$ in $D_{\text {va }}$ (Fig. 13). This mode grew conspicuously in the sulfate size distribution during the $\mathrm{T} 0$ to $\mathrm{T} 1$ transport periods (Fig. 13b). It was also visible, but with lower intensity and larger mode size, during the downslope wind periods. This mode was barely noticeable during the northwesterly wind periods. The strong enhancement of small mode particles in the urban transport air mass was associated with the frequent occurrence of new particle growth events during which the formation and condensation of $\mathrm{H}_{2} \mathrm{SO}_{4}$ and SOA species led to the growth of newly formed particles.

SOA formation in different air masses can be investigated using the $\triangle \mathrm{OA} / \triangle \mathrm{CO}$ ratio to take into account of the dilution effect of primary emissions. $\triangle \mathrm{OA}$ and $\Delta \mathrm{CO}$ correspond to the organic aerosol and CO concentrations above their respective background levels, and were determined for the three air masses separately based on the averages of the lowest $5 \%$ data. $\triangle \mathrm{OA}$ was $0.3 \mu \mathrm{g} \mathrm{m}^{-3}$ in each air mass, while $\Delta \mathrm{CO}$ was 85 (T0 $\rightarrow \mathrm{T} 1$ transport), 80 (northwesterly wind periods) and 90 (other periods) ppb respectively. Figure 14 shows the relationships between $\triangle \mathrm{OA}$ and $\triangle \mathrm{CO}$ during the entire campaign, as well as for different air masses and periods with different concentrations of biogenic VOCs. $\triangle \mathrm{OA}$ and $\triangle \mathrm{CO}$ were weakly correlated during this study $\left(r^{2}=0.22\right.$; Fig. 14a), while the correlation was found to be much higher during a recent field campaign performed at the Blodgett Forest $\left(r^{2}=0.79\right.$; Worton et al., 2011). The ratio of $\triangle \mathrm{OA}$ to $\Delta \mathrm{CO}$ varied between $5-196 \mu \mathrm{g} \mathrm{m}^{-3} \mathrm{ppm}^{-1}$ (Fig. 14a), indicating large variations in SOA formation rates. The minimum value of this study $\left(5 \mu \mathrm{g} \mathrm{m}^{-3} \mathrm{ppm}^{-1}\right)$ was very close to the $\mathrm{HOA} / \mathrm{CO}\left(4 \mu \mathrm{g} \mathrm{m}^{-3} \mathrm{ppm}^{-1}\right)$ ratio observed at an urban location - Pittsburgh (Zhang et al., 2005c), consistent with influence from primary combustion emissions.

The diurnal pattern of $\Delta \mathrm{OA} / \Delta \mathrm{CO}$ showed a gradual increase between 10:00 $\left(50 \mu \mathrm{g} \mathrm{m}^{-3} \mathrm{ppm}^{-1}\right)$ and 17:00 (72 $\mu \mathrm{g} \mathrm{m}^{-3} \mathrm{ppm}^{-1}$; Fig. 14b). This time period corresponded to the urban plume from $\mathrm{T} 0$ to $\mathrm{T} 1$. The diurnal pattern of $\Delta \mathrm{OA} / \triangle \mathrm{CO}$ showed another gradual increase between 23:00 $\left(41 \mu \mathrm{g} \mathrm{m}^{-3} \mathrm{ppm}^{-1}\right)$ and 03:00 $\left(61 \mu \mathrm{g} \mathrm{m}^{-3} \mathrm{ppm}^{-1}\right)$. This period corresponded to nocturnal downslope winds which brought a part of the polluted air back from the Sierra Mountains to the foothills. The increase of $\Delta \mathrm{OA} / \Delta \mathrm{CO}$ during this period $\left(20 \mu \mathrm{g} \mathrm{m}^{-3} \mathrm{ppm}^{-1}\right)$ was comparable to that during the daytime transport events $\left(22 \mu \mathrm{g} \mathrm{m}^{-3} \mathrm{ppm}^{-1}\right)$. These results indicate that SOA formation was enhanced at T1 during periods when the site was more strongly influenced by anthropogenic emissions.

An important parameter in the comparison between different air masses is the photochemical age. Unfortunately, we were not able to determine this parameter with the data acquired at $\mathrm{T} 1$. Gas phase toluene and benzene data were too noisy because of low concentrations. Since $\mathrm{NO}_{\mathrm{x}}$ was not measured at $\mathrm{T} 1$ the $\mathrm{NO}_{\mathrm{x}} / \mathrm{NO}_{\mathrm{y}}$ ratio could not be used either. de Gouw et al. (2008) derived an equation that relates 

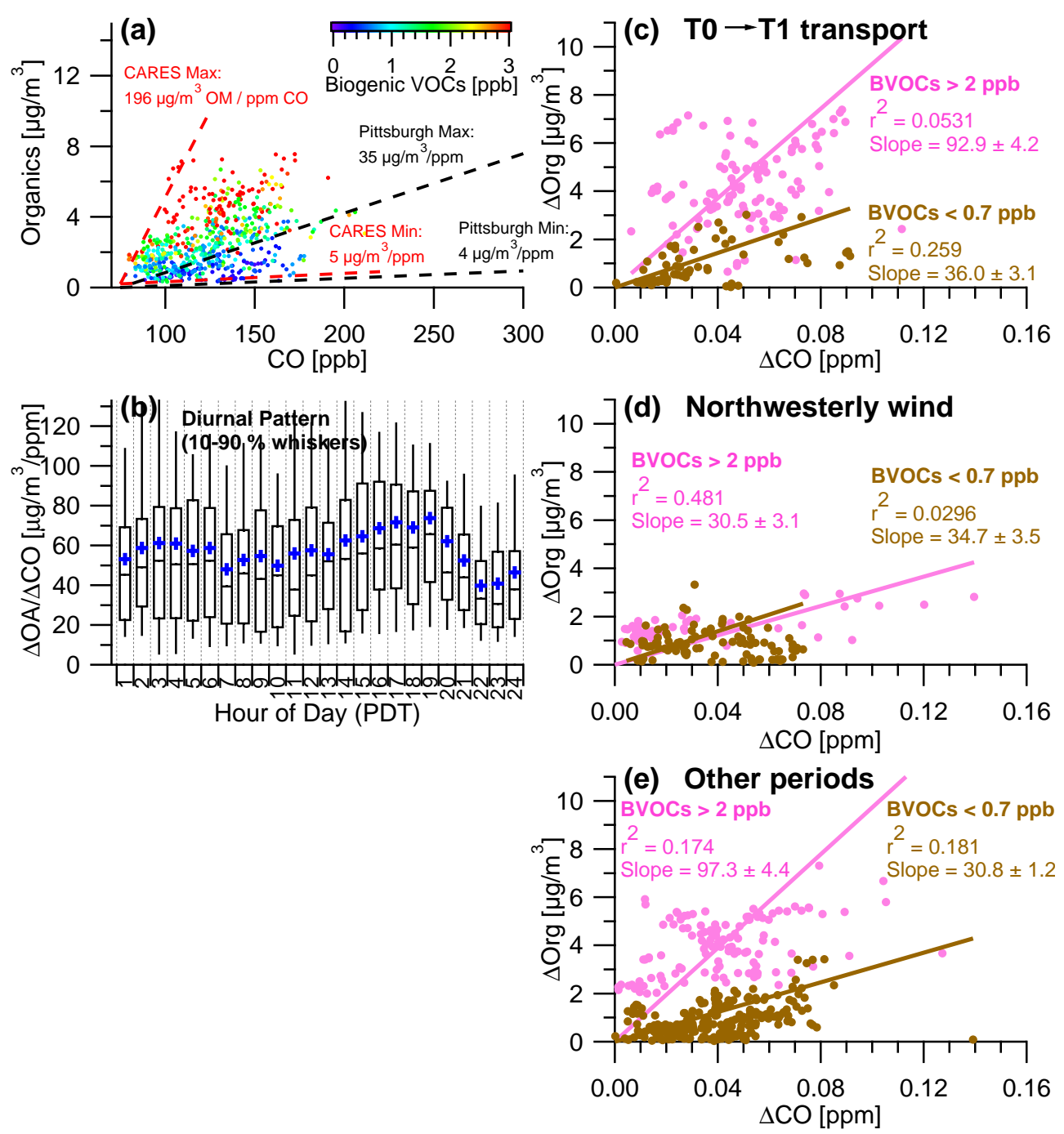

Fig. 14. (a) Scatterplot of organics vs. CO, colored by the sum of biogenic VOCs (= isoprene + monoterpenes + 2-methyl-3-buten-2-ol $[\mathrm{MBO}]+$ methyl chavicol). (b) Diurnal pattern of $\Delta \mathrm{OA} / \Delta \mathrm{CO}$. Scatterplot of $\Delta \mathrm{OA} / \Delta \mathrm{CO}$ during three air mass types as marked on Fig. 2: (c) T0 to T1 transport, (d) northwesterly wind and (e) other periods. In (c), (d), and (e), the data points are classified into periods of high $(>2 \mathrm{ppb})$ or low $(<0.7 \mathrm{ppb})$ mixing ratios of biogenic VOCs. Box plots: whiskers correspond to the 10th and 90th percentile, boxes to the 25th and 75th percentile, the horizontal marks in the boxes to the median, and the colored crosses to the mean. The data fitting (c, d, e) was performed using the orthogonal distance regression (ODR).

$\Delta \mathrm{OC} / \Delta \mathrm{CO}$ (the increase of organic carbon mass relative to the increase of $\mathrm{CO})$ to the photochemical age $(\Delta \mathrm{t}$ in hour) based on ambient measurements in the northeastern US in summer:

$$
\begin{aligned}
& \Delta \mathrm{OC} / \Delta \mathrm{CO}=5.3 \times \exp (-0.00677 \times \Delta t)+57 \\
& \times(\exp (-0.00677 \times \Delta t)-\exp (-0.0384 \times \Delta t))
\end{aligned}
$$

Using the $\triangle \mathrm{OA} / \triangle \mathrm{CO}$ and $\mathrm{OM} / \mathrm{OC}$ values from this study, we determined that the average $\Delta \mathrm{OC} / \Delta \mathrm{CO}$ during this study was $21 \mu \mathrm{gC} \mathrm{m}{ }^{-3} \mathrm{ppm}^{-1}$. The average ratios for different air masses were $25 \mu \mathrm{gC} \mathrm{m}^{-3} \mathrm{ppm}^{-1}$ (T0 to $\mathrm{T} 1$ transport), $17 \mu \mathrm{gC} \mathrm{m}^{-3} \mathrm{ppm}^{-1}$ (northwesterly wind), and $21 \mu \mathrm{gC} \mathrm{m}{ }^{-3} \mathrm{ppm}^{-1}$ (other periods). According to Eq. (3), the
$\Delta \mathrm{OC} / \Delta \mathrm{CO}$ for periods of urban transport would correspond to a photochemical age of $\sim 16 \mathrm{~h}$, much longer than the time needed for particles to be transported from T0 to T1. The $\mathrm{T} 0 \rightarrow \mathrm{T} 1$ transport time was estimated at $2-8 \mathrm{~h}$ based on model predictions (Fast et al., 2012) as well as comparisons of observations at T1 and T0, e.g., the time delays between the onset of the new particle growth events and the peaking times of pollutants. This is also in agreement with Dillon et al. (2002), who determined that the Sacramento urban plume takes on average $5 \mathrm{~h}$ to reach the Blodgett Forest. Apparently, the relationship derived from the northeastern US does not apply to the Sacramento Valley Air Basin, where the type 
and concentration of precursors, meteorological conditions, and concentrations of oxidants are vastly different.

As shown in Fig. 14c-e, the slope of $\triangle \mathrm{OA}$ vs. $\triangle \mathrm{CO}$ depends strongly on the amount of biogenic VOCs present during these periods, suggesting that the enhancement of SOA formation due to anthropogenic influences is also dependent on the amount of biogenic VOCs available. To calculate the sum of biogenic VOCs, we took into account of isoprene, monoterpenes, MBO and methyl chavicol, knowing that isoprene was by far the most abundant biogenic VOC measured during this study ( $82 \%$ of the total biogenic VOCs in average). Note that the temporal variations of the different biogenic VOCs are very different (Fig. S1 in the Supplement), isoprene being dominant during the day while monoterpenes were higher during the night and obviously transported during the downslope flows from the Sierra Nevada to the foothills. During the transport periods from $\mathrm{T} 0$ to $\mathrm{T} 1$ (Fig. 14c), the slope of $\triangle \mathrm{OA}$ vs. $\triangle \mathrm{CO}$ increased by a factor of 3 when the sum of biogenic VOCs was higher than $2 \mathrm{ppb}$, compared to periods when the mixing ratio was lower than $0.7 \mathrm{ppb}$ (93 vs. $36 \mu \mathrm{g} \mathrm{m}^{-3} \mathrm{ppm}^{-1}$ ). This change in SOA mass relative to $\mathrm{CO}$ was approximately the same as that during the downslope flows $\left(97 \mu \mathrm{g} \mathrm{m}^{-3} \mathrm{ppm}^{-1}\right.$; Fig. 14e) when anthropogenic influences were still present, but was much higher than during the northwesterly wind periods $\left(31 \mu \mathrm{g} \mathrm{m}^{-3} \mathrm{ppm}^{-1}\right.$; Fig. 14d) dominated by biogenic SOAs. In summary, these results suggest that the SOA formation was enhanced when anthropogenic influences increased at Cool, but only if significant amounts of biogenic precursors were present. The observations from this study also support the hypothesis that the interaction between anthropogenic and biogenic precursors enhances the SOA formation (de Gouw et al., 2005; Volkamer et al., 2006; Weber et al., 2007; Kleinman et al., 2008).

\section{Conclusions}

An HR-ToF-AMS and an SMPS were deployed at Cool, $\mathrm{CA}$, the $\mathrm{T} 1$ rural site of the CARES field campaign in June 2010 to characterize the mass concentration, chemical composition and size distributions of submicrometer aerosols. The sampling site was located at the foothills of the Sierra Nevada Mountains, where biogenic emissions from forests are periodically mixed with urban outflow transported by consistent southwest winds from Sacramento. The average mass loading during the entire campaign was $3.0 \mu \mathrm{g} \mathrm{m}^{-3}$, with organics ( $80 \%$ of the total $\mathrm{PM}_{1}$ mass) being the dominant component followed by sulfate $(9.9 \%)$, ammonium $(4.5 \%)$, nitrate $(3.6 \%)$, black carbon $(1.6 \%)$, and chloride $(0.1 \%)$. The amount of ammonium appeared to be in charge balance with observed anions (sum of $\mathrm{SO}_{4}^{2-}+\mathrm{NO}_{3}^{-}+\mathrm{Cl}^{-}$), indicating that sulfate was mainly present in the form of $\left(\mathrm{NH}_{4}\right)_{2} \mathrm{SO}_{4}$. The average size distribution indicated that sulfate was mainly present in the accumulation mode $\left(D_{\mathrm{va}}\right.$
200-600 nm) whereas organics showed broader distributions peaking at smaller sizes. New particle formation and growth events were observed almost every day with the SMPS. Our results showed that organics and, to a lesser extent, sulfate played key roles in the new particle growth. Three OA factors were identified by PMF analysis of the high resolution mass spectra, including two distinct OOA factors $(91 \%$ of total organics) and an HOA (9\%). The more oxidized MO$\mathrm{OOA}(\mathrm{O} / \mathrm{C}=0.54)$ was found to represent biogenically influenced SOA, while the less oxidized LO-OOA $(\mathrm{O} / \mathrm{C}=0.42)$ corresponded to anthropogenically influenced SOA mainly formed in the air mass transported from the Sacramento area. The HOA factor corresponded to primary emissions from local sources. The diurnal variation patterns of LO-OOA, ozone, and sulfate were very similar and all showed substantial daytime increases consistent with impacts from urban transport. However, the time series of LO-OOA and sulfate were poorly correlated, indicating different source regions of their precursor species and different formation mechanisms. For instance, the prominent droplet mode of sulfate and the tight correlation between sulfate and MSA indicate a significant influence of aqueous-phase reactions on sulfate production. A large fraction of this droplet mode may come from the San Francisco Bay Area, where oil refineries are the largest $\mathrm{SO}_{2}$ sources identified in northern California and where aqueous reactions would have been promoted by fogs and low clouds during morning hours around the Bay Area. The good correlations observed between MOOOA and first generation isoprene photooxidation products (MVK and MACR) and between LO-OOA and ozone suggest that both SOA types were relatively fresh, which were consistent with their relatively low $\mathrm{O} / \mathrm{C}$ ratios.

23 periods of urban plumes from T0 (Sacramento) to T1 (Cool) were identified using the WRF-Chem model. The average chemical composition of aerosols was overall similar in different air masses. $\mathrm{PM}_{1}$ mass loading, however, was more than twice higher during the $\mathrm{T} 0$ to $\mathrm{T} 1$ transport periods than during northwesterly wind periods ( $3.9 \mathrm{vs} .1 .8 \mu \mathrm{g} \mathrm{m}^{-3}$ ). In addition, a second mode of sulfate in small sizes ( $D_{\text {va }}$ $100-150 \mathrm{~nm}$ ) became conspicuous during the T0 to T1 transport periods, due to the frequent occurrence of new particle growth events in urban plumes. This mode was less obvious in air masses dominated by biogenic SOAs and almost disappeared during northwesterly wind periods. $\triangle \mathrm{OA} / \Delta \mathrm{CO}$, an indicator for SOA production, varied in the range of 5$196 \mu \mathrm{g} \mathrm{m}^{-3} \mathrm{ppm}^{-1}$ during this study. Enhanced SOA formation was observed when urban emissions from Sacramento arrived at $\mathrm{T} 1$ and interacted with biogenic precursors. Moreover, the largest SOA formation was observed in urban plumes mixed with a high concentration of biogenic VOCs. For example, in air masses influenced by urban emissions, $\Delta \mathrm{OA} / \Delta \mathrm{CO}$ values were on average above $90 \mu \mathrm{g} \mathrm{m}^{-3} \mathrm{ppm}^{-1}$ in the presence of high biogenic VOCs ( $>2 \mathrm{ppb}$ ), compared to $36 \mu \mathrm{g} \mathrm{m}^{-3} \mathrm{ppm}^{-1}$ at low biogenic VOCs $(<0.7 \mathrm{ppb})$. The average $\Delta \mathrm{OA} / \Delta \mathrm{CO}$ was $30-35 \mu \mathrm{g} \mathrm{m}^{-3} \mathrm{ppm}^{-1}$ in air masses 
dominated by biogenic SOA with little anthropogenic influence (i.e., during the northwesterly wind periods).

\section{Supplementary material related to this article is available online at: http://www.atmos-chem-phys.net/12/ 8131/2012/acp-12-8131-2012-supplement.pdf.}

Acknowledgements. This research was supported by the California Air Resource Board (CARB), Agreement No. 10-305, the Office of Science (BER), US Department of Energy (DOE), Atmospheric System Research Program, Grant No. DE-FG02-11ER65293, and the California Agricultural Experiment Station (Project CA-DETX-2102-H).

Edited by: J. Thornton

\section{References}

Aiken, A. C., Decarlo, P. F., Kroll, J. H., Worsnop, D. R., Huffman, J. A., Docherty, K. S., Ulbrich, I. M., Mohr, C., Kimmel, J. R., Sueper, D., Sun, Y. L., Zhang, Q., Trimborn, A., Northway, M., Ziemann, P. J., Canagaratna, M. R., Onasch, T. B., Alfarra, M. R., Prevot, A. S. H., Dommen, J., Duplissy, J., Metzger, A., Baltensperger, U., and Jimenez, J. L.: O/C and OM/OC ratios of primary, secondary, and ambient organic aerosols with highresolution time-of-flight aerosol mass spectrometry, Environ. Sci. Technol., 42, 4478-4485, doi:10.1021/es703009q, 2008.

Aiken, A. C., Salcedo, D., Cubison, M. J., Huffman, J. A., DeCarlo, P. F., Ulbrich, I. M., Docherty, K. S., Sueper, D., Kimmel, J. R., Worsnop, D. R., Trimborn, A., Northway, M., Stone, E. A., Schauer, J. J., Volkamer, R. M., Fortner, E., de Foy, B., Wang, J., Laskin, A., Shutthanandan, V., Zheng, J., Zhang, R., Gaffney, J., Marley, N. A., Paredes-Miranda, G., Arnott, W. P., Molina, L. T., Sosa, G., and Jimenez, J. L.: Mexico City aerosol analysis during MILAGRO using high resolution aerosol mass spectrometry at the urban supersite (T0) - Part 1: Fine particle composition and organic source apportionment, Atmos. Chem. Phys., 9, 6633-6653, doi:10.5194/acp-9-6633-2009, 2009.

Aiken, A. C., de Foy, B., Wiedinmyer, C., DeCarlo, P. F., Ulbrich, I. M., Wehrli, M. N., Szidat, S., Prevot, A. S. H., Noda, J., Wacker, L., Volkamer, R., Fortner, E., Wang, J., Laskin, A., Shutthanandan, V., Zheng, J., Zhang, R., Paredes-Miranda, G., Arnott, W. P., Molina, L. T., Sosa, G., Querol, X., and Jimenez, J. L.: Mexico city aerosol analysis during MILAGRO using high resolution aerosol mass spectrometry at the urban supersite (T0) Part 2: Analysis of the biomass burning contribution and the non-fossil carbon fraction, Atmos. Chem. Phys., 10, 5315-5341, doi:10.5194/acp-10-5315-2010, 2010

Alfarra, M. R.: Insights Into Atmospheric Organic Aerosols Using An Aerosol Mass Spectrometer, PhD Dissertation Thesis, Department of Chemical Engineering, University of Manchester, Manchester, UK, 2004.

Alfarra, M. R., Coe, H., Allan, J. D., Bower, K. N., Boudries, H., Canagaratna, M. R., Jimenez, J. L., Jayne, J. T., Garforth, A. A.,
Li, S. M., and Worsnop, D. R.: Characterization of urban and rural organic particulate in the lower Fraser valley using two aerodyne aerosol mass spectrometers, Atmos. Environ., 38, 57455758, doi:10.1016/j.atmosenv.2004.01.054, 2004.

Alfarra, M. R., Paulsen, D., Gysel, M., Garforth, A. A., Dommen, J., Prevot, A. S. H., Worsnop, D. R., Baltensperger, U., and Coe, H.: A mass spectrometric study of secondary organic aerosols formed from the photooxidation of anthropogenic and biogenic precursors in a reaction chamber, Atmos. Chem. Phys., 6, 52795293, doi:10.5194/acp-6-5279-2006, 2006.

Alfarra, M. R., Prevot, A. S. H., Szidat, S., Sandradewi, J., Weimer, S., Lanz, V. A., Schreiber, D., Mohr, M., and Baltensperger, U.: Identification of the Mass Spectral Signature of Organic Aerosols from Wood Burning Emissions, Environ. Sci. Technol. 41, 5770-5777, doi:10.1021/es062289b, 2007.

Allan, J. D., Delia, A. E., Coe, H., Bower, K. N., Alfarra, M. R., Jimenez, J. L., Middlebrook, A. M., Drewnick, F., Onasch, T. B., Canagaratna, M. R., Jayne, J. T., and Worsnop, D. R.: A generalised method for the extraction of chemically resolved mass spectra from aerodyne aerosol mass spectrometer data, J. Aerosol. Sci., 35, 909-922, doi:10.1016/j.jaerosci.2004.02.007, 2004.

Allan, J. D., Alfarra, M. R., Bower, K. N., Coe, H., Jayne, J. T., Worsnop, D. R., Aalto, P. P., Kulmala, M., Hyotylainen, T., Cavalli, F., and Laaksonen, A.: Size and composition measurements of background aerosol and new particle growth in a Finnish forest during QUEST 2 using an Aerodyne Aerosol Mass Spectrometer, Atmos. Chem. Phys., 6, 315-327, doi:10.5194/acp-6-315-2006, 2006.

Allan, J. D., Williams, P. I., Morgan, W. T., Martin, C. L., Flynn, M. J., Lee, J., Nemitz, E., Phillips, G. J., Gallagher, M. W., and Coe, H.: Contributions from transport, solid fuel burning and cooking to primary organic aerosols in two UK cities, Atmos. Chem. Phys., 10, 647-668, doi:10.5194/acp-10-647-2010, 2010.

Apel, E. C., Riemer, D. D., Hills, A., Baugh, W., Orlando, J., Faloona, I., Tan, D., Brune, W., Lamb, B., Westberg, H., Carroll, M. A., Thornberry, T., and Geron, C. D.: Measurement and interpretation of isoprene fluxes and isoprene, methacrolein, and methyl vinyl ketone mixing ratios at the PROPHET site during the 1998 Intensive, J. Geophys. Res., 107, 4034, doi:10.1029/2000jd000225, 2002.

Barnes, I., Hjorth, J., and Mihalopoulos, N.: Dimethyl Sulfide and Dimethyl Sulfoxide and Their Oxidation in the Atmosphere, Chem. Rev., 106, 940-975, doi:10.1021/cr020529, 2006.

Birmili, W., Stratmann, F., Wiedensohler, A., Covert, D., Russell, L. M., and Berg, O.: Determination of differential mobility analyzer transfer functions using identical instruments in series, Aerosol Sci. Technol., 27, 215-223, doi:10.1080/02786829708965468, 1997.

Bond, T. C. and Bergstrom, R. W.: Light Absorption by Carbonaceous Particles: An Investigative Review, Aerosol Sci. Technol., 40, 27-67, doi:10.1080/02786820500421521, 2006.

Bouvier-Brown, N. C., Goldstein, A. H., Gilman, J. B., Kuster, W. C., and de Gouw, J. A.: In-situ ambient quantification of monoterpenes, sesquiterpenes, and related oxygenated compounds during BEARPEX 2007: implications for gas- and particle-phase chemistry, Atmos. Chem. Phys., 9, 5505-5518, doi:10.5194/acp-9-5505-2009, 2009. 
Cahill, T. M., Seaman, V. Y., Charles, M. J., Holzinger, R., and Goldstein, A. H.: Secondary organic aerosols formed from oxidation of biogenic volatile organic compounds in the Sierra Nevada Mountains of California, J. Geophys. Res.-Atmos., 111, D16312, doi:10.1029/2006jd007178, 2006.

Canagaratna, M. R., Jayne, J. T., Jimenez, J. L., Allan, J. D., Alfarra, M. R., Zhang, Q., Onasch, T. B., Drewnick, F., Coe, H., Middlebrook, A., Delia, A., Williams, L. R., Trimborn, A. M., Northway, M. J., DeCarlo, P. F., Kolb, C. E., Davidovits, P., and Worsnop, D. R.: Chemical and microphysical characterization of ambient aerosols with the aerodyne aerosol mass spectrometer, Mass Spectrom. Rev., 26, 185-222, doi:10.1002/mas.20115, 2007.

Chen, Q., Farmer, D. K., Schneider, J., Zorn, S. R., Heald, C. L., Karl, T. G., Guenther, A., Allan, J. D., Robinson, N., Coe, H., Kimmel, J. R., Pauliquevis, T., Borrmann, S., Po uml schl, U., Andreae, M. O., Artaxo, P., Jimenez, J. L., and Martin, S. T.: Mass spectral characterization of submicron biogenic organic particles in the Amazon Basin, Geophys. Res. Lett., 36, L20806, doi:10.1029/2009g1039880, 2009.

Chhabra, P. S., Flagan, R. C., and Seinfeld, J. H.: Elemental analysis of chamber organic aerosol using an aerodyne high-resolution aerosol mass spectrometer, Atmos. Chem. Phys., 10, 4111-4131, doi:10.5194/acp-10-4111-2010, 2010.

Chhabra, P. S., Ng, N. L., Canagaratna, M. R., Corrigan, A. L., Russell, L. M., Worsnop, D. R., Flagan, R. C., and Seinfeld, J. H.: Elemental composition and oxidation of chamber organic aerosol, Atmos. Chem. Phys., 11, 8827-8845, doi:10.5194/acp-11-88272011, 2011.

Clausnitzer, H. and Singer, M. J.: Respirable-Dust Production from Agricultural Operations in the Sacramento Valley, California, J. Environ. Qual., 25, 877-884, 10.2134/jeq1996.00472425002500040032x, 1996.

Cottrell, L. D., Griffin, R. J., Jimenez, J. L., Zhang, Q., Ulbrich, I., Ziemba, L. D., Beckman, P. J., Sive, B. C., and Talbot, R. W.: Submicron particles at Thompson Farm during ICARTT measured using aerosol mass spectrometry, J. Geophys. Res.-Atmos., 113, D08212, doi:10.1029/2007jd009192, 2008.

Creamean, J. M., Ault, A. P., Ten Hoeve, J. E., Jacobson, M. Z., Roberts, G. C., and Prather, K. A.: Measurements of Aerosol Chemistry during New Particle Formation Events at a Remote Rural Mountain Site, Environ. Sci. Technol., 45, 8208-8216, doi:10.1021/es103692f, 2011.

de Gouw, J. and Warneke, C.: Measurements of volatile organic compounds in the earths atmosphere using proton-transferreaction mass spectrometry, Mass Spectrom. Rev., 26, 223-257, doi:10.1002/mas.20119, 2007.

de Gouw, J. A., Middlebrook, A. M., Warneke, C., Goldan, P. D., Kuster, W. C., Roberts, J. M., Fehsenfeld, F. C., Worsnop, D. R., Canagaratna, M. R., Pszenny, A. A. P., Keene, W. C., Marchewka, M., Bertman, S. B., and Bates, T. S.: Budget of organic carbon in a polluted atmosphere: Results from the New England Air Quality Study in 2002, J. Geophys. Res.-Atmos., 110, D16305, doi:10.1029/2004jd005623, 2005.

de Gouw, J. A., Brock, C. A., Atlas, E. L., Bates, T. S., Fehsenfeld, F. C., Goldan, P. D., Holloway, J. S., Kuster, W. C., Lerner, B. M., Matthew, B. M., Middlebrook, A. M., Onasch, T. B., Peltier, R. E., Quinn, P. K., Senff, C. J., Stohl, A., Sullivan, A. P., Trainer, M., Warneke, C., Weber, R. J., and Williams, E. J.:
Sources of particulate matter in the northeastern United States in summer: 1. Direct emissions and secondary formation of organic matter in urban plumes, J. Geophys. Res.-Atmos., 113, D08301, doi:10.1029/2007jd009243, 2008.

DeCarlo, P. F., Slowik, J. G., Worsnop, D. R., Davidovits, P., and Jimenez, J. L.: Particle morphology and density characterization by combined mobility and aerodynamic diameter measurements. Part 1: Theory, Aerosol Sci. Technol., 38, 1185-1205, doi:10.1080/027868290903907, 2004.

DeCarlo, P. F., Kimmel, J. R., Trimborn, A., Northway, M. J., Jayne, J. T., Aiken, A. C., Gonin, M., Fuhrer, K., Horvath, T., Docherty, K. S., Worsnop, D. R., and Jimenez, J. L.: Field-deployable, high-resolution, time-of-flight aerosol mass spectrometer, Anal. Chem., 78, 8281-8289, doi:10.1021/ac061249n, 2006.

DeCarlo, P. F., Dunlea, E. J., Kimmel, J. R., Aiken, A. C., Sueper, D., Crounse, J., Wennberg, P. O., Emmons, L., Shinozuka, Y., Clarke, A., Zhou, J., Tomlinson, J., Collins, D. R., Knapp, D., Weinheimer, A. J., Montzka, D. D., Campos, T., and Jimenez, J. L.: Fast airborne aerosol size and chemistry measurements above Mexico City and Central Mexico during the MILAGRO campaign, Atmos. Chem. Phys., 8, 4027-4048, doi:10.5194/acp-84027-2008, 2008.

Dillon, M. B., Lamanna, M. S., Schade, G. W., Goldstein, A. H., and Cohen, R. C.: Chemical evolution of the Sacramento urban plume: Transport and oxidation, J. Geophys. Res.-Atmos., 107, 4045, doi:10.1029/2001jd000969, 2002.

Dzepina, K., Volkamer, R. M., Madronich, S., Tulet, P., Ulbrich, I. M., Zhang, Q., Cappa, C. D., Ziemann, P. J., and Jimenez, J. L.: Evaluation of recently-proposed secondary organic aerosol models for a case study in Mexico City, Atmos. Chem. Phys., 9, 5681-5709, doi:10.5194/acp-9-5681-2009, 2009.

Ervens, B., Turpin, B. J., and Weber, R. J.: Secondary organic aerosol formation in cloud droplets and aqueous particles (aqSOA): a review of laboratory, field and model studies, Atmos. Chem. Phys., 11, 11069-11102, doi:10.5194/acp-11-110692011, 2011.

Farmer, D. K., Matsunaga, A., Docherty, K. S., Surratt, J. D., Seinfeld, J. H., Ziemann, P. J., and Jimenez, J. L.: Response of an aerosol mass spectrometer to organonitrates and organosulfates and implications for atmospheric chemistry, Proc. Natl. Acad. Sci. USA, 107, 6670-6675, doi:10.1073/pnas.0912340107, 2010.

Farmer, D. K., Kimmel, J. R., Phillips, G., Docherty, K. S., Worsnop, D. R., Sueper, D., Nemitz, E., and Jimenez, J. L.: Eddy covariance measurements with high-resolution time-offlight aerosol mass spectrometry: a new approach to chemically resolved aerosol fluxes, Atmos. Meas. Tech., 4, 1275-1289, doi:10.5194/amt-4-1275-2011, 2011.

Fast, J. D., Gustafson Jr, W. I., Berg, L. K., Shaw, W. J., Pekour, M., Shrivastava, M., Barnard, J. C., Ferrare, R. A., Hostetler, C. A., Hair, J. A., Erickson, M., Jobson, B. T., Flowers, B., Dubey, M. K., Springston, S., Pierce, R. B., Dolislager, L., Pederson, J., and Zaveri, R. A.: Transport and mixing patterns over Central California during the carbonaceous aerosol and radiative effects study (CARES), Atmos. Chem. Phys., 12, 1759-1783, doi:10.5194/acp-12-1759-2012, 2012.

Ge, X., Zhang, Q., Sun, Y. L., Ruehl, C. R., and Setyan, A.: Effect of aqueous-phase processing on aerosol chemistry and size distributions in Fresno, California, during wintertime, Environmental 
Chemistry, 9, 221-235, doi:10.1071/EN11168, 2012.

Goldstein, A. H., Hultman, N. E., Fracheboud, J. M., Bauer, M. R., Panek, J. A., Xu, M., Qi, Y., Guenther, A. B., and Baugh, W.: Effects of climate variability on the carbon dioxide, water, and sensible heat fluxes above a ponderosa pine plantation in the Sierra Nevada (CA), Agric. For. Meteorol., 101, 113-129, doi:10.1016/S0168-1923(99)00168-9, 2000.

Goldstein, A. H., Koven, C. D., Heald, C. L., and Fung, I. Y.: Biogenic carbon and anthropogenic pollutants combine to form a cooling haze over the southeastern United States, Proceedings of the National Academy of Sciences, 106, 8835-8840, doi:10.1073/pnas.0904128106, 2009.

Hallquist, M., Wenger, J. C., Baltensperger, U., Rudich, Y., Simpson, D., Claeys, M., Dommen, J., Donahue, N. M., George, C., Goldstein, A. H., Hamilton, J. F., Herrmann, H., Hoffmann, T., Iinuma, Y., Jang, M., Jenkin, M. E., Jimenez, J. L., KiendlerScharr, A., Maenhaut, W., McFiggans, G., Mentel, T. F., Monod, A., Prévôt, A. S. H., Seinfeld, J. H., Surratt, J. D., Szmigielski, R., and Wildt, J.: The formation, properties and impact of secondary organic aerosol: current and emerging issues, Atmos. Chem. Phys., 9, 5155-5236, doi:10.5194/acp-9-5155-2009, 2009.

Herndon, S. C., Onasch, T. B., Wood, E. C., Kroll, J. H., Canagaratna, M. R., Jayne, J. T., Zavala, M. A., Knighton, W. B., Mazzoleni, C., Dubey, M. K., Ulbrich, I. M., Jimenez, J. L., Seila, R., de Gouw, J. A., de Foy, B., Fast, J., Molina, L. T., Kolb, C. E., and Worsnop, D. R.: Correlation of secondary organic aerosol with odd oxygen in Mexico City, Geophys. Res. Lett., 35, L15804, doi:10.1029/2008g1034058, 2008.

Hildebrandt, L., Engelhart, G. J., Mohr, C., Kostenidou, E., Lanz, V. A., Bougiatioti, A., DeCarlo, P. F., Prevot, A. S. H., Baltensperger, U., Mihalopoulos, N., Donahue, N. M., and Pandis, S. N.: Aged organic aerosol in the Eastern Mediterranean: the Finokalia Aerosol Measurement Experiment-2008, Atmos. Chem. Phys., 10, 4167-4186, doi:10.5194/acp-10-4167-2010, 2010.

Holmes, N. S.: A review of particle formation events and growth in the atmosphere in the various environments and discussion of mechanistic implications, Atmos. Environ., 41, 2183-2201, doi:10.1016/j.atmosenv.2006.10.058, 2007.

Holzinger, R., Lee, A., Paw, K. T., and Goldstein, A. H.: Observations of oxidation products above a forest imply biogenic emissions of very reactive compounds, Atmos. Chem. Phys., 5, 6775, doi:10.5194/acp-5-67-2005, 2005

Holzinger, R., Millet, D. B., Williams, B., Lee, A., Kreisberg, N., Hering, S. V., Jimenez, J., Allan, J. D., Worsnop, D. R., and Goldstein, A. H.: Emission, oxidation, and secondary organic aerosol formation of volatile organic compounds as observed at Chebogue Point, Nova Scotia, J. Geophys. Res.-Atmos., 112, D10S24, doi:10.1029/2006jd007599, 2007.

Hoyle, C. R., Boy, M., Donahue, N. M., Fry, J. L., Glasius, M., Guenther, A., Hallar, A. G., Hartz, K. H., Petters, M. D., Petaja, T., Rosenoern, T., and Sullivan, A. P.: A review of the anthropogenic influence on biogenic secondary organic aerosol, Atmos. Chem. Phys., 11, 321-343, doi:10.5194/acp-11-321-2011, 2011.

IPCC: Summary for Policymakers, in: Climate Change 2007: The Physical Science Basis. Contribution of Working Group I to the Fourth Assessment Report of the Intergovernmental Panel on Climate Change, edited by: Solomon, S., Qin, D., Manning, M., Chen, Z., Marquis, M., Averyt, K. B., M.Tignor, and Miller, H.
L., Cambridge University Press, Cambridge, UK and New York, NY, USA, 1-18, 2007.

Jacob, D. J., Field, B. D., Jin, E. M., Bey, I., Li, Q., Logan, J. A., Yantosca, R. M., and Singh, H. B.: Atmospheric budget of acetone, J. Geophys. Res., 107, 4100, doi:10.1029/2001jd000694, 2002.

Jacob, D. J., Field, B. D., Li, Q., Blake, D. R., de Gouw, J., Warneke, C., Hansel, A., Wisthaler, A., Singh, H. B., and Guenther, A.: Global budget of methanol: Constraints from atmospheric observations, J. Geophys. Res., 110, D08303, doi:10.1029/2004jd005172, 2005.

Jayne, J. T., Leard, D. C., Zhang, X. F., Davidovits, P., Smith, K. A., Kolb, C. E., and Worsnop, D. R.: Development of an aerosol mass spectrometer for size and composition analysis of submicron particles, Aerosol Sci. Technol., 33, 49-70, doi:10.1080/027868200410840, 2000.

Jimenez, J. L., Canagaratna, M. R., Donahue, N. M., Prevot, A. S. H., Zhang, Q., Kroll, J. H., DeCarlo, P. F., Allan, J. D., Coe, H., Ng, N. L., Aiken, A. C., Docherty, K. S., Ulbrich, I. M., Grieshop, A. P., Robinson, A. L., Duplissy, J., Smith, J. D., Wilson, K. R., Lanz, V. A., Hueglin, C., Sun, Y. L., Tian, J., Laaksonen, A., Raatikainen, T., Rautiainen, J., Vaattovaara, P., Ehn, M., Kulmala, M., Tomlinson, J. M., Collins, D. R., Cubison, M J., Dunlea, E. J., Huffman, J. A., Onasch, T. B., Alfarra, M. R., Williams, P. I., Bower, K., Kondo, Y., Schneider, J., Drewnick, F., Borrmann, S., Weimer, S., Demerjian, K., Salcedo, D., Cottrell, L., Griffin, R., Takami, A., Miyoshi, T., Hatakeyama, S., Shimono, A., Sun, J. Y., Zhang, Y. M., Dzepina, K., Kimmel, J. R., Sueper, D., Jayne, J. T., Herndon, S. C., Trimborn, A. M., Williams, L. R., Wood, E. C., Middlebrook, A. M., Kolb, C. E., Baltensperger, U., and Worsnop, D. R.: Evolution of Organic Aerosols in the Atmosphere, Science, 326, 1525-1529, 10.1126/science.1180353, 2009.

John, W., Wall, S. M., Ondo, J. L., and Winklmayr, W.: Modes in the size distributions of atmospheric inorganic aerosol, Atmospheric Environment. Part A, General Topics, 24, 2349-2359, doi:10.1016/0960-1686(90)90327-j, 1990.

Kanakidou, M., Tsigaridis, K., Dentener, F. J., and Crutzen, P. J.: Human-activity-enhanced formation of organic aerosols by biogenic hydrocarbon oxidation, J. Geophys. Res., 105, 9243-9354, doi:10.1029/1999jd901148, 2000.

Kanakidou, M., Seinfeld, J. H., Pandis, S. N., Barnes, I., Dentener, F. J., Facchini, M. C., Van Dingenen, R., Ervens, B., Nenes, A., Nielsen, C. J., Swietlicki, E., Putaud, J. P., Balkanski, Y., Fuzzi, S., Horth, J., Moortgat, G. K., Winterhalter, R., Myhre, C. E. L., Tsigaridis, K., Vignati, E., Stephanou, E. G., and Wilson, J.: Organic aerosol and global climate modelling: a review, Atmos. Chem. Phys., 5, 1053-1123, doi:10.5194/acp-5-1053-2005, 2005.

Kiendler-Scharr, A., Zhang, Q., Hohaus, T., Kleist, E., Mensah, A., Mentel, T. F., Spindler, C., Uerlings, R., Tillmann, R., and Wildt, J.: Aerosol Mass Spectrometric Features of Biogenic SOA: Observations from a Plant Chamber and in Rural Atmospheric Environments, Environ. Sci. Technol., 43, 8166-8172, doi:10.1021/es901420b, 2009.

Kleinman, L. I., Daum, P. H., Lee, Y.-N., Senum, G. I., Springston, S. R., Wang, J., Berkowitz, C., Hubbe, J., Zaveri, R. A., Brechtel, F. J., Jayne, J., Onasch, T. B., and Worsnop, D.: Aircraft observations of aerosol composition and ageing in New England and 
Mid-Atlantic States during the summer 2002 New England Air Quality Study field campaign, J. Geophys. Res., 112, D09310, doi:10.1029/2006jd007786, 2007.

Kleinman, L. I., Springston, S. R., Daum, P. H., Lee, Y. N., Nunnermacker, L. J., Senum, G. I., Wang, J., Weinstein-Lloyd, J., Alexander, M. L., Hubbe, J., Ortega, J., Canagaratna, M. R., and Jayne, J.: The time evolution of aerosol composition over the Mexico City plateau, Atmos. Chem. Phys., 8, 1559-1575, doi:10.5194/acp-8-1559-2008, 2008.

Kuwata, M., Zorn, S. R., and Martin, S. T.: Using Elemental Ratios to Predict the Density of Organic Material Composed of Carbon, Hydrogen, and Oxygen, Environ. Sci. Technol., 46, 787794, doi:10.1021/es202525q, 2012.

Lambe, A. T., Onasch, T. B., Massoli, P., Croasdale, D. R., Wright, J. P., Ahern, A. T., Williams, L. R., Worsnop, D. R., Brune, W. H., and Davidovits, P.: Laboratory studies of the chemical composition and cloud condensation nuclei $(\mathrm{CCN})$ activity of secondary organic aerosol (SOA) and oxidized primary organic aerosol (OPOA), Atmos. Chem. Phys., 11, 8913-8928, doi:10.5194/acp11-8913-2011, 2011.

Lanz, V. A., Alfarra, M. R., Baltensperger, U., Buchmann, B., Hueglin, C., and Prevot, A. S. H.: Source apportionment of submicron organic aerosols at an urban site by factor analytical modelling of aerosol mass spectra, Atmos. Chem. Phys., 7, 15031522, doi:10.5194/acp-7-1503-2007, 2007.

Lanz, V. A., Prevot, A. S. H., Alfarra, M. R., Weimer, S., Mohr, C., DeCarlo, P. F., Gianini, M. F. D., Hueglin, C., Schneider, J., Favez, O., D’Anna, B., George, C., and Baltensperger, U.: Characterization of aerosol chemical composition with aerosol mass spectrometry in Central Europe: an overview, Atmos. Chem. Phys., 10, 10453-10471, doi:10.5194/acp-10-104532010, 2010.

Lee, A., Goldstein, A. H., Keywood, M. D., Gao, S., Varutbangkul, V., Bahreini, R., Ng, N. L., Flagan, R. C., and Seinfeld, J. H.: Gas-phase products and secondary aerosol yields from the ozonolysis of ten different terpenes, J. Geophys. Res.-Atmos., 111, D07302, doi:10.1029/2005jd006437, 2006.

Lunden, M. M., Black, D. R., McKay, M., Revzan, K. L., Goldstein, A. H., and Brown, N. J.: Characteristics of fine particle growth events observed above a forested ecosystem in the Sierra Nevada Mountains of California, Aerosol Sci. Technol., 40, 373388, doi:10.1080/02786820600631896, 2006.

Mahowald, N.: Aerosol Indirect Effect on Biogeochemical Cycles and Climate, Science, 334, 794-796, doi:10.1126/science.1207374, 2011.

Matthew, B. M., Middlebrook, A. M., and Onasch, T. B.: Collection efficiencies in an Aerodyne Aerosol Mass Spectrometer as a function of particle phase for laboratory generated aerosols, Aerosol Sci. Technol., 42, 884-898, doi:10.1080/02786820802356797, 2008.

McKendry, I. G., Macdonald, A. M., Leaitch, W. R., van Donkelaar, A., Zhang, Q., Duck, T., and Martin, R. V.: Trans-Pacific dust events observed at Whistler, British Columbia during INTEXB, Atmos. Chem. Phys., 8, 6297-6307, doi:10.5194/acp-8-62972008, 2008.

McLafferty, F. W., and Turecek, F.: Interpretation of mass spectra, Fourth ed., University Science Books, Mill Valley, California, USA, 1993.
Meng, Z. and Seinfeld, J. H.: On the Source of the Submicrometer Droplet Mode of Urban and Regional Aerosols, Aerosol Sci. Technol., 20, 253-265, doi:10.1080/02786829408959681, 1994.

Middlebrook, A. M., Bahreini, R., Jimenez, J. L., and Canagaratna, M. R.: Evaluation of Composition-Dependent Collection Efficiencies for the Aerodyne Aerosol Mass Spectrometer using Field Data, Aerosol Sci. Technol., 46, 258-271, doi:10.1080/02786826.2011.620041, 2012.

Mohr, C., Huffman, J. A., Cubison, M. J., Aiken, A. C., Docherty, K. S., Kimmel, J. R., Ulbrich, I. M., Hannigan, M., and Jimenez, J. L.: Characterization of Primary Organic Aerosol Emissions from Meat Cooking, Trash Burning, and Motor Vehicles with High-Resolution Aerosol Mass Spectrometry and Comparison with Ambient and Chamber Observations, Environ. Sci. Technol., 43, 2443-2449, doi:10.1021/es8011518, 2009.

Murphy, J. G., Day, D. A., Cleary, P. A., Wooldridge, P. J., Millet, D. B., Goldstein, A. H., and Cohen, R. C.: The weekend effect within and downwind of Sacramento - Part 1: Observations of ozone, nitrogen oxides, and VOC reactivity, Atmos. Chem. Phys., 7, 5327-5339, doi:10.5194/acp-7-5327-2007, 2007.

Ng, N. L., Canagaratna, M. R., Zhang, Q., Jimenez, J. L., Tian, J., Ulbrich, I. M., Kroll, J. H., Docherty, K. S., Chhabra, P. S., Bahreini, R., Murphy, S. M., Seinfeld, J. H., Hildebrandt, L., Donahue, N. M., DeCarlo, P. F., Lanz, V. A., Prevot, A. S. H., Dinar, E., Rudich, Y., and Worsnop, D. R.: Organic aerosol components observed in Northern Hemispheric datasets from Aerosol Mass Spectrometry, Atmos. Chem. Phys., 10, 46254641, doi:10.5194/acp-10-4625-2010, 2010.

Ng, N. L., Canagaratna, M. R., Jimenez, J. L., Chhabra, P. S., Seinfeld, J. H., and Worsnop, D. R.: Changes in organic aerosol composition with aging inferred from aerosol mass spectra, Atmos. Chem. Phys., 11, 6465-6474, doi:10.5194/acp-11-64652011, 2011a.

Ng, N. L., Canagaratna, M. R., Jimenez, J. L., Zhang, Q., Ulbrich, I. M., and Worsnop, D. R.: Real-Time Methods for Estimating Organic Component Mass Concentrations from Aerosol Mass Spectrometer Data, Environ. Sci. Technol., 45, 910-916, doi:10.1021/es102951k, 2011b.

Paatero, P., and Tapper, U.: Positive Matrix Factorization A Nonnegative Factor Model with Optimal Utilization of Error-Estimates of Data Values, Environmetrics, 5, 111-126, doi:10.1002/env.3170050203, 1994.

Pope, C. A., Ezzati, M., and Dockery, D. W.: Fine-Particulate Air Pollution and Life Expectancy in the United States, New England Journal of Medicine, 360, 376-386, doi:10.1056/NEJMsa0805646, 2009.

Raatikainen, T., Vaattovaara, P., Tiitta, P., Miettinen, P., Rautiainen, J., Ehn, M., Kulmala, M., Laaksonen, A., and Worsnop, D. R.: Physicochemical properties and origin of organic groups detected in boreal forest using an aerosol mass spectrometer, Atmos. Chem. Phys., 10, 2063-2077, doi:10.5194/acp-10-20632010, 2010.

Rollins, A. W., Fry, J. L., Hunter, J. F., Kroll, J. H., Worsnop, D. R., Singaram, S. W., and Cohen, R. C.: Elemental analysis of aerosol organic nitrates with electron ionization high-resolution mass spectrometry, Atmos. Meas. Tech., 3, 301-310, doi:10.5194/amt3-301-2010, 2010.

Schade, G. W. and Goldstein, A. H.: Fluxes of oxygenated volatile organic compounds from a ponderosa pine 
plantation, J. Geophys. Res.-Atmos., 106, 3111-3123, doi:10.1029/2000JD900592, 2001.

Schade, G. W. and Goldstein, A. H.: Seasonal measurements of acetone and methanol: Abundances and implications for atmospheric budgets, Global Biogeochem. Cy., 20, GB1011, doi:10.1029/2005GB002566, 2006.

Sharkey, T. D., Singsaas, E. L., Vanderveer, P. J., and Geron, C.: Field measurements of isoprene emission from trees in response to temperature and light, Tree Physiol., 16, 649-654, doi:10.1093/treephys/16.7.649, 1996.

Shilling, J. E., Chen, Q., King, S. M., Rosenoern, T., Kroll, J. H., Worsnop, D. R., DeCarlo, P. F., Aiken, A. C., Sueper, D., Jimenez, J. L., and Martin, S. T.: Loading-dependent elemental composition of alpha-pinene SOA particles, Atmos. Chem. Phys., 9, 771-782, doi:10.5194/acp-9-771-2009, 2009.

Slowik, J. G., Stroud, C., Bottenheim, J. W., Brickell, P. C., Chang, R. Y. W., Liggio, J., Makar, P. A., Martin, R. V., Moran, M. D., Shantz, N. C., Sjostedt, S. J., van Donkelaar, A., Vlasenko, A., Wiebe, H. A., Xia, A. G., Zhang, J., Leaitch, W. R., and Abbatt, J. P. D.: Characterization of a large biogenic secondary organic aerosol event from eastern Canadian forests, Atmos. Chem. Phys., 10, 2825-2845, doi:10.5194/acp-10-2825-2010, 2010.

Spaulding, R. S., Schade, G. W., Goldstein, A. H., and Charles, M. J.: Characterization of secondary atmospheric photooxidation products: Evidence for biogenic and anthropogenic sources, J. Geophys. Res.-Atmos., 108, 4247, doi:10.1029/2002jd002478, 2003.

Spracklen, D. V., Jimenez, J. L., Carslaw, K. S., Worsnop, D. R., Evans, M. J., Mann, G. W., Zhang, Q., Canagaratna, M. R., Allan, J., Coe, H., McFiggans, G., Rap, A., and Forster, P.: Aerosol mass spectrometer constraint on the global secondary organic aerosol budget, Atmos. Chem. Phys., 11, 12109-12136, doi:10.5194/acp-11-12109-2011, 2011.

Subramanian, R., Kok, G. L., Baumgardner, D., Clarke, A., Shinozuka, Y., Campos, T. L., Heizer, C. G., Stephens, B. B., de Foy, B., Voss, P. B., and Zaveri, R. A.: Black carbon over Mexico: the effect of atmospheric transport on mixing state, mass absorption cross-section, and BC/CO ratios, Atmos. Chem. Phys., 10, 219237, doi:10.5194/acp-10-219-2010, 2010.

Sun, J. Y., Zhang, Q., Canagaratna, M. R., Zhang, Y. M., Ng, N. L., Sun, Y. L., Jayne, J. T., Zhang, X. C., Zhang, X. Y., and Worsnop, D. R.: Highly time- and size-resolved characterization of submicron aerosol particles in Beijing using an Aerodyne Aerosol Mass Spectrometer, Atmos. Environ., 44, 131-140, doi:10.1016/j.atmosenv.2009.03.020, 2010.

Sun, Y. L., Zhang, Q., Macdonald, A. M., Hayden, K., Li, S. M., Liggio, J., Liu, P. S. K., Anlauf, K. G., Leaitch, W. R., Steffen, A., Cubison, M., Worsnop, D. R., van Donkelaar, A., and Martin, R. V.: Size-resolved aerosol chemistry on Whistler Mountain, Canada with a high-resolution aerosol mass spectrometer during INTEX-B, Atmos. Chem. Phys., 9, 3095-3111, doi:10.5194/acp9-3095-2009, 2009.

Sun, Y. L., Zhang, Q., Schwab, J. J., Demerjian, K. L., Chen, W. N., Bae, M. S., Hung, H. M., Hogrefe, O., Frank, B., Rattigan, O. V., and Lin, Y. C.: Characterization of the sources and processes of organic and inorganic aerosols in New York city with a high-resolution time-of-flight aerosol mass apectrometer, Atmos. Chem. Phys., 11, 1581-1602, doi:10.5194/acp-11-15812011, 2011.
Takegawa, N., Miyakawa, T., Kawamura, K., and Kondo, Y.: Contribution of Selected Dicarboxylic and $\omega$-Oxocarboxylic Acids in Ambient Aerosol to the $\mathrm{m} / \mathrm{z} 44$ Signal of an Aerodyne Aerosol Mass Spectrometer, Aerosol Sci. Technol., 41, 418-437, doi:10.1080/02786820701203215, 2007.

Ulbrich, I. M., Canagaratna, M. R., Zhang, Q., Worsnop, D. R., and Jimenez, J. L.: Interpretation of organic components from Positive Matrix Factorization of aerosol mass spectrometric data, Atmos. Chem. Phys., 9, 2891-2918, doi:10.5194/acp-9-2891-2009, 2009.

Ulbrich, I. M., Canagaratna, M. R., Cubison, M. J., Zhang, Q., Ng, N. L., Aiken, A. C., and Jimenez, J. L.: Three-dimensional factorization of size-resolved organic aerosol mass spectra from Mexico City, Atmos. Meas. Tech., 5, 195-224, doi:10.5194/amt-5195-2012, 2012.

Vaden, T. D., Imre, D., Beranek, J., Shrivastava, M., and Zelenyuk, A.: Evaporation kinetics and phase of laboratory and ambient secondary organic aerosol, Proc. Natl. Acad. Sci. USA, 108, 2190-2195, doi:10.1073/pnas.1013391108, 2011.

Volkamer, R., Jimenez, J. L., San Martini, F., Dzepina, K., Zhang, Q., Salcedo, D., Molina, L. T., Worsnop, D. R., and Molina, M. J.: Secondary organic aerosol formation from anthropogenic air pollution: Rapid and higher than expected, Geophys. Res. Lett., 33, L17811, doi:10.1029/2006g1026899, 2006.

Watson, J. G.: Visibility: Science and regulation, J. Air Waste Manage. Assoc., 52, 628-713, doi:10.1080/10473289.2002.10470813, 2002.

Weber, R. J., Sullivan, A. P., Peltier, R. E., Russell, A., Yan, B., Zheng, M., de Gouw, J., Warneke, C., Brock, C., Holloway, J. S., Atlas, E. L., and Edgerton, E.: A study of secondary organic aerosol formation in the anthropogenic-influenced southeastern United States, J. Geophys. Res.-Atmos., 112, D13302, doi:10.1029/2007jd008408, 2007.

Wiedensohler, A.: An approximation of the bipolar charge distribution for particles in the submicron size range, J. Aerosol. Sci., 19, 387-389, doi:10.1016/0021-8502(88)90278-9, 1988.

Wiedensohler, A., Birmili, W., Nowak, A., Sonntag, A., Weinhold, K., Merkel, M., Wehner, B., Tuch, T., Pfeifer, S., Fiebig, M., Fjäraa, A. M., Asmi, E., Sellegri, K., Depuy, R., Venzac, H., Villani, P., Laj, P., Aalto, P., Ogren, J. A., Swietlicki, E., Williams, P., Roldin, P., Quincey, P., Hüglin, C., Fierz-Schmidhauser, R., Gysel, M., Weingartner, E., Riccobono, F., Santos, S., Grüning, C., Faloon, K., Beddows, D., Harrison, R., Monahan, C., Jennings, S. G., O’Dowd, C. D., Marinoni, A., Horn, H. G., Keck, L., Jiang, J., Scheckman, J., McMurry, P. H., Deng, Z., Zhao, C. S., Moerman, M., Henzing, B., de Leeuw, G., Löschau, G., and Bastian, S.: Mobility particle size spectrometers: harmonization of technical standards and data structure to facilitate high quality long-term observations of atmospheric particle number size distributions, Atmos. Meas. Tech., 5, 657-685, doi:10.5194/amt5-657-2012, 2012.

Williams, B. J., Goldstein, A. H., Millet, D. B., Holzinger, R., Kreisberg, N. M., Hering, S. V., White, A. B., Worsnop, D. R., Allan, J. D., and Jimenez, J. L.: Chemical speciation of organic aerosol during the International Consortium for Atmospheric Research on Transport and Transformation 2004: Results from in situ measurements, J. Geophys. Res.-Atmos., 112, D10S26, doi:10.1029/2006jd007601, 2007. 
Winklmayr, W., Reischl, G. P., Lindner, A. O., and Berner, A.: A New Electromobility Spectrometer for the Measurement of Aerosol Size Distributions in the Size Range from 1 to 1000 nm, J. Aerosol. Sci., 22, 289-296, doi:10.1016/S00218502(05)80007-2, 1991.

Wood, E. C., Canagaratna, M. R., Herndon, S. C., Onasch, T. B., Kolb, C. E., Worsnop, D. R., Kroll, J. H., Knighton, W. B., Seila, R., Zavala, M., Molina, L. T., DeCarlo, P. F., Jimenez, J. L., Weinheimer, A. J., Knapp, D. J., Jobson, B. T., Stutz, J., Kuster, W. C., and Williams, E. J.: Investigation of the correlation between odd oxygen and secondary organic aerosol in Mexico City and Houston, Atmos. Chem. Phys., 10, 8947-8968, doi:10.5194/acp-10-8947-2010, 2010.

Worton, D. R., Goldstein, A. H., Farmer, D. K., Docherty, K. S., Jimenez, J. L., Gilman, J. B., Kuster, W. C., de Gouw, J., Williams, B. J., Kreisberg, N. M., Hering, S. V., Bench, G., McKay, M., Kristensen, K., Glasius, M., Surratt, J. D., and Seinfeld, J. H.: Origins and composition of fine atmospheric carbonaceous aerosol in the Sierra Nevada Mountains, California, Atmos. Chem. Phys., 11, 10219-10241, doi:10.5194/acp-1110219-2011, 2011.

Zaveri, R. A., Easter, R. C., Fast, J. D., and Peters, L. K.: Model for Simulating Aerosol Interactions and Chemistry (MOSAIC), J. Geophys. Res.-Atmos., 113, D13204, doi:10.1029/2007jd008782, 2008.

Zaveri, R. A., Shaw, W. J., Cziczo, D. J., Schmid, B., Ferrare, R. A., Alexander, M. L., Alexandrov, M., Alvarez, R. J., Arnott, W. P., Atkinson, D. B., Baidar, S., Banta, R. M., Barnard, J. C., Beranek, J., Berg, L. K., Brechtel, F., Brewer, W. A., Cahill, J. F., Cairns, B., Cappa, C. D., Chand, D., China, S., Comstock, J. M., Dubey, M. K., Easter, R. C., Erickson, M. H., Fast, J. D., Floerchinger, C., Flowers, B. A., Fortner, E., Gaffney, J. S., Gilles, M. K., Gorkowski, K., Gustafson, W. I., Gyawali, M., Hair, J., Hardesty, R. M., Harworth, J. W., Herndon, S., Hiranuma, N., Hostetler, C., Hubbe, J. M., Jayne, J. T., Jeong, H., Jobson, B. T., Kassianov, E. I., Kleinman, L. I., Kluzek, C., Knighton, B., Kolesar, K. R., Kuang, C., Kubátová, A., Langford, A. O., Laskin, A., Laulainen, N., Marchbanks, R. D., Mazzoleni, C., Mei, F., Moffet, R. C., Nelson, D., Obland, M. D., Oetjen, H., Onasch, T. B., Ortega, I., Ottaviani, M., Pekour, M., Prather, K. A., Radney, J. G., Rogers, R. R., Sandberg, S. P., Sedlacek, A., Senff, C. J., Senum, G., Setyan, A., Shilling, J. E., Shrivastava, M., Song, C., Springston, S. R., Subramanian, R., Suski, K., Tomlinson, J., Volkamer, R., Wallace, H. W., Wang, J., Weickmann, A. M., Worsnop, D. R., Yu, X. Y., Zelenyuk, A., and Zhang, Q.: Overview of the 2010 Carbonaceous Aerosols and Radiative Effects Study (CARES), Atmos. Chem. Phys., 12, 7647-7687, doi:10.5194/acp-12-7647-2012, 2012.
Zhang, Q., Stanier, C. O., Canagaratna, M. R., Jayne, J. T., Worsnop, D. R., Pandis, S. N., and Jimenez, J. L.: Insights into the chemistry of new particle formation and growth events in Pittsburgh based on aerosol mass spectrometry, Environ. Sci. Technol., 38, 4797-4809, doi:10.1021/es035417u, 2004.

Zhang, Q., Alfarra, M. R., Worsnop, D. R., Allan, J. D., Coe, H., Canagaratna, M. R., and Jimenez, J. L.: Deconvolution and quantification of hydrocarbon-like and oxygenated organic aerosols based on aerosol mass spectrometry, Environ. Sci. Technol., 39, 4938-4952, doi:10.1021/es0485681, 2005a.

Zhang, Q., Canagaratna, M. R., Jayne, J. T., Worsnop, D. R., and Jimenez, J. L.: Time- and size-resolved chemical composition of submicron particles in Pittsburgh: Implications for aerosol sources and processes, J. Geophys. Res.-Atmos., 110, D07S09, doi:10.1029/2004jd004649, 2005b.

Zhang, Q., Worsnop, D. R., Canagaratna, M. R., and Jimenez, J. L.: Hydrocarbon-like and oxygenated organic aerosols in Pittsburgh: insights into sources and processes of organic aerosols, Atmos. Chem. Phys., 5, 3289-3311, doi:10.5194/acp-5-32892005, 2005c.

Zhang, Q., Jimenez, J. L., Canagaratna, M. R., Allan, J. D., Coe, H., Ulbrich, I., Alfarra, M. R., Takami, A., Middlebrook, A. M., Sun, Y. L., Dzepina, K., Dunlea, E., Docherty, K., DeCarlo, P. F., Salcedo, D., Onasch, T., Jayne, J. T., Miyoshi, T., Shimono, A., Hatakeyama, S., Takegawa, N., Kondo, Y., Schneider, J., Drewnick, F., Borrmann, S., Weimer, S., Demerjian, K., Williams, P., Bower, K., Bahreini, R., Cottrell, L., Griffin, R. J., Rautiainen, J., Sun, J. Y., Zhang, Y. M., and Worsnop, D. R.: Ubiquity and dominance of oxygenated species in organic aerosols in anthropogenically-influenced Northern Hemisphere midlatitudes, Geophys. Res. Lett., 34, L13801, doi:10.1029/2007g1029979, 2007a.

Zhang, Q., Jimenez, J. L., Worsnop, D. R., and Canagaratna, M.: A case study of urban particle acidity and its influence on secondary organic aerosol, Environ. Sci. Technol., 41, 3213-3219, doi:10.1021/es061812j, 2007b.

Zhang, Q., Jimenez, J., Canagaratna, M., Ulbrich, I., Ng, N., Worsnop, D., and Sun, Y. L.: Understanding atmospheric organic aerosols via factor analysis of aerosol mass spectrometry: a review, Analytical and Bioanalytical Chemistry, 401, 3045-3067, doi:10.1007/s00216-011-5355-y, 2011. 